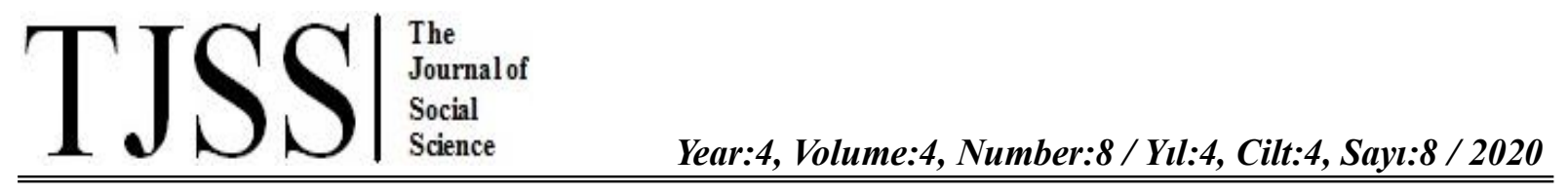

DOI Number: 10.30520/tjsosci.667778

\title{
MODERN SOYKIRIM İLE LINÇ KÜLTÜRÜ ARASINDA KALAN SURIYYELİ SIĞINMACILARIN SUÇ OLGUSUNA KARŞI DURUŞLARI: BATMAN ÖRNEĞİ
}

\author{
ATTITUDE OF SYRIAN REFUGEES FOR CRIME, WHO EXPERIENCED MODERN \\ GENOCIDE AND LYNCH CULTURE: BATMAN CITY EXAMPLE
}

Serkan KÜÇÜKDOĞRU ${ }^{1}$

\section{ÖZET}

Arap Bahar'ının kelebek etkisiyle Ortadoğu'da hızla yayılması sonucunda oluşturduğu etki alanından en fazla etkilenen ülke sonuçları itibariyle Suriye'dir. Suriye'de yaşanan insan hakları ihlalleri sonucunda "kavimler göçü" diyebileceğimiz bir oranda Türkiye'ye zorunlu ve kitlesel göçlerin hala devam ettiği görülmektedir. Başlangıçta "misafir" olarak görülen Suriyeliler, uzun misafirlik süresi sonrasında "komşu" olarak görülmeye başlanmıştır. Türkiye' de zaman zaman görülen sosyal, siyasi ve ekonomik problemler, dijital basın ve sosyal medya yoluyla oluşturulan temelsiz algılar, terör eylemleri gibi yaşanan hadiselerle birleştiği zaman sığınmacılar aleyhine bazı önyargılar oluşmaktadır. Göçmen karşitlığına dönüşen bu önyargılar, ötekileştirmeye, popülizmin tetiklenmesine neden olmaktadır. Tüm bu sürecin sonunda çoğu ekonomik açıdan problemli ve eğitimsiz olan bu insanların, suç işlemeye meyilli oldukları, Türkiye'de meydana gelen adli olaylarda ciddi katkıları bulundukları gibi görüşler ortaya çıkmaktadır. Türkiye' deki suç verileri bu görüşlerin ötekileştirme sonucu ortaya atıldıklarını onaylamaktadır. Çalışmada yukarıda bahsedilen durumlara yer verilerek, Batman örneği kapsamında 2018 ve 2019 suç verileri incelenerek Suriyelilerin suça karışma durumları ile ilgili önemli çıkarımlarda bulunulacaktır.

Anahtar Kelimeler: Suriyeli sığınmacılar, popülizm, suç, göç, güvenlik

\begin{abstract}
Syria is the most affected country by the Arab spring that rapidly spread in the Middle East by the butterfly effect. Forced mass migrations to the size of the migration period continue to Turkey. The Syrians, who initially considered "guests", considered as "neighbors" after a long stay. Social, political and economic problems that encountered from time to time in Turkey, misperceptions created through digital press and social media and terror attacks cause some kind of prejudices against migrants. These prejudices which turn into anti-migration lead to othering and trigger populism. Some opinions are emerging such as mostly uneducated and economically problematic migrants tend to commit a crime and they have significant contributions to incidents occur in Turkey. Crime data in Turkey confirm that these opinions are the results of othering. In this study, the above-mentioned situations will be included and the crime data of 2018 and 2019 will be examined within the scope of Batman City and important inferences will be made regarding the cases of Syrian Migrants involvement in crime.
\end{abstract}

Keywords: Syrian migrants, populism, crime, migration, security

\footnotetext{
${ }^{1}$ Dr. Serkan KÜÇÜKDOĞRU, Batman İl Emniyet Müdürlüğü, serkan98036@gmail.com
} 


\section{GİRIŞ}

2010 yılı sonlarında Tunus’ta başlayıp, kısa zamanda Ortadoğu'da hızla yayılarak Tunus, Mısır, Libya gibi ülkelerin rejimlerini yıkan, devlet başkanlarınca önemli reform vaatleri sunması nedeniyle Suudi Arabistan, Fas, Lübnan gibi ülkeler de kontrol altına alınan, Arap halklarının özgürlük, eşitlik, adalet gibi idelerle başlayan halk hareketi, "Arap Baharı” olarak adlandırılmış, bu süreç sonrasında Suriye'deki halk ayaklanmaları kontrol edilemez hal almış olmasına rağmen rejime yönelik değişim hareketleri başarılı olamamıştır.

Suriye'de protestoların önemli bir çoğunluğu kuzeyinde yer alan Hama, İdlib, Lazkiye ve Humus 'ta ortaya çıkmış, daha sonra Şam'ın bazı bölgelerine ve daha küçük ölçüde Halep'e siçramıştır (Euro-Mediterranean Human Rights, 2011: 4).

Suriye rejimi, halkının ayaklanma hareketlerini bastırmada orantısız güç kullanmıştır. Bu süreç maalesef Arap Baharının en kanlı süreci olmuş ve Suriye bölgenin en kanlı çatışmalarının yaşandığ 1 ülke olmuştur. Buradaki rejim güçleri ile muhalifler arasındaki yoğun çatışmalar, orantısız güç kullanımı ve biyolojik silahların kullanımı, ciddi ve ağır insan hakları ihlallerine neden olmuştur.

Suriye'nin Arap Baharı öncesindeki durumuna göz attığımızda bölgede daha önceden de devam eden iç savaştan söz etmek mümkündür. Bölgede zaten var olan etnik ve dini grupların çatışmalarını körükleyen dış aktörler bu süreci daha kolay tetiklemiş, meydana gelen çatışma ortamının günden güne daha da şiddetlenmesine neden olmuştur.

Rejimden ve destekçi dış aktörlerden kaynaklı yaşanan insanlık dramları sonucu milyonlarca Suriyeli evlerinden, ülkesinden göç ettirilmeye, yer değiştirilmeye zorlanmıştır. "Suriye rejimini engelleme çabaları Rusya, Çin ve İran gibi dış aktörlerin mevcut Suriye yönetimini desteklemeleri ve bu ülkelerden Birleşmiş Milletler Güvenlik Konseyi'nin daimi üyeleri olan Rusya ve Çin'in Suriye'ye yaptırım kararını devamlı olarak veto etmesiyle başarısız olmuş, BM'nin Suriye'deki iç savaşı durdurabilmek için rejimi ile muhalefet arasında diyalog kurma çabasıyla gerçekleştirilen Cenevre Görüşmeleri de sorunu çözmede yetersiz kalmıştır” (Aşkar, 2017: 135).

Görüldüğü gibi uluslararası arenada bu drama maalesef ki çözüm bulunamamış, insan hakları ihlallerini engelleme çabaları sonuçsuz kalmış, Suriyeliler kendi vatanlarında kaderlerine mahkûm edilmiştir.

Şüphesiz insani olanaklarını gerçekleştirebilme ve güvenli bölgelerde yaşama isteği, bölge halkını gerek ülke içerisinde gerekse ülke dışına zorunlu göç etmeye mecbur kılmıştır.

2010 y1lı Suriye nüfusu 21.5 milyon civarındaydı. Suriye'de hayatını kaybedenlerin sayısı en az 250 bine, evinden edilenlerin sayısı ise 12-13 milyona ulaşırken, ülkesini terk edenler 5-6 milyon civarında olarak belirlenmiş durumdadır (İKV, 2016: 5).

Görüldüğü üzere; "Modern soykırım" olarak da adlandırabileceğimiz bu süreç, ne yazık ki 2011 Nisan'dan günümüze sadece 21 milyon civarı insanı etkilememiş, aynı zamanda sonuçları göz önünde bulundurulduğunda, başta Türkiye olmak üzere, sinır ülkelerine ve hatta $A B$ ülkelerine tesir eden olumsuz etkilerini görmek mümkündür. Kısacası Suriye meselesi, bölgesel bir sorun olmaktan öte, küresel bir sorun haline gelerek, evrensel boyutta değerlendirilmelidir.

Yoğun insan hakları ihlalleri beraberinde zorunlu göç dalgalarına sebep olmuş, şüphesiz bu minvalde bundan en çok etkilenen ülke Türkiye'dir. Türkiye bu duruma sessiz kalmayarak, çatışma ortamının yaşandığı ilk günden bu güne, yardım elini hiçbir zaman eksik etmemiştir, 
misafirperverlik duygularıyla hareket ederek ortaya koyduğu "açık kapı" politikası gereği, ağır zulüm altında kalan insanlara, ülke kapılarını sonuna kadar açmıştır.

Türkiye'ye Nisan 2011 tarihinden itibaren, bölgede mağdur olan Suriyelilere yönelik "açık kap1 politikası" nı ilan etmiş, 100.000 kişilik kritik eşik seviyesini de dile getirilmiştir. Fakat bu eşik, saldırıların şiddetlenmesi ve yaşam koşullarının zayıflaması nedeniyle aşılmış, beklenenin çok üzerinde göçmen Türkiye'ye kabul edilmiştir. Buna rağmen, bu politika gereği Suriyeliler günümüzde hala kabul edilmektedir.

Bu çerçevede Türkiye'ye ilk grup resmî olarak 29 Nisan 2011 'de gelmiştir. 252 kişilik bu grup herhangi bir engelle karşılaşmadan Yayladağı ilçesindeki Cilvegözü Sınır Kapısı'ndan giriş yaparak Türkiye'ye sığınmıştır (TBMM, 2012: 2). Göç İdaresi Genel Müdürlüğü'nün 2019 Ekim ayı verileri incelendiğinde, bu sayının 3.676.288 kişiye ulaştığını, bunların \% 54,2'sinin erkek, \% 45,8'inin kadın olduğunu görmekteyiz. Nihai olarak; sürecin öngörülemeyen bir süreç olduğunu, misafir Suriyeli sayılarındaki küçümsenmeyecek artışa rağmen, Türkiye'nin başta yaşam hakkı olmak üzere, insan hakları konusundaki hassasiyetlerinin ne denli ciddi olduğunu açıkça görmekteyiz.

$\mathrm{Bu}$ öngörülemeyen sürecin yaşanmasında, zorunlu göçün gerçekleşmeye başladığı ilk anlarda Suriye'deki çatışma durumunun bölgedeki diğer ülkelere benzer bir biçimde kısa sürede rejim değişikliği ile sonuçlanacağı düşüncesinin hâkim olması etkili olmuştur. Ardından Suriyeli mülteciler, misafir olarak tanımlanarak geçici barınma merkezlerine yerleştirilmeleri öngörülmüş, Suriyeli mülteciler misafir olarak tanımlanmıştırlar (Mutlu, Mısırlı, Kahveci, Akyol, Erol, Gümüşcan, Pınar ve Salman, 2018: 70).

Türkiye, hâlihazırda 3,7 milyona yakın Suriyeliyi misafir etmektedir. Yıl bazında nüfusa oranlandığında bu sayı Türkiye'ye gerek ekonomik gerekse sosyal ve siyasal anlamda yükümlülükler yüklemiştir. Bu kadar çok sayıda sığınmacının Türkiye'ye gelmesi, hem Türkiye'de hem sınır hattında hem de $\mathrm{AB}$ ülkelerinde çeşitli güvenlik riskleri oluşturacağ 1 aşikârdır. Bu göç dalgası nedeniyle, Türkiye'deki mevcut durum bütünüyle değerlendirilmeli, sosyolojik, ekonomik ve kamu düzeni açısından sorunlar hassasiyetle araştırılmalı, gerekli tedbirler alınmalıdır.

Suriyeli sığınmacılar meselesi, yukarıda bahsettiğimiz üzere sadece Türkiye’yi ilgilendiren bir sorun ötesinde küresel boyutu da ihtiva eden bir problemdir. Türkiye, Suriyeli sığınmacılar için hem ilk durak, hem de $\mathrm{AB}$ ülkelerine açılan önemli bir geçiş yolu rotası niteliğindedir. İlk zorunlu göçmen bloğunun Suriye'den çıkışından itibaren bugüne kadar, $A B$ ülkelerine ulaşanların sayısı milyonlarla ifade edilmektedir. Sadece 2015 yılında bu say1 1 milyonun üzerindedir. Sadece Suriye'den zorunlu göç eden insanlar için değil aynı zamanda AB ülkelerine ulaşma hayali kuran insanlar için de Türkiye, önemli bir geçiş güzergâhına sahip olmasinın yanında, zorunlu bir rota durumundadir.

Avrupa ülkelerine ulaşmak isteyen mülteciler, Akdeniz'de canlarını hiçe sayarcasına yolculuğu göze almışlardır. İnsanların her geçen gün daha fazla ölüme zorlandığı bir güzergâh haline gelen Akdeniz'de, sadece 2015 yılında 5 bin 400, 2016 yılının ilk dört ayında bin 638 göçmen hayatlarını kaybetmiştir (İKV, 2016: 4-5). Bu insani durum küresel basında da geniş yankılar uyandırmıştır.

$\mathrm{AB}$ ülkelerine ulaşabilen sı̆̆ınmacılar tarafından, $\mathrm{AB}$ ülkelerinde gerçekleştirdikleri terör eylemlerinin IŞİD, DAEŞ terör örgütü adı altında üstlenilmesi, farklı güvenlik endişelerine yol açmıştır. Özellikle 2015 yılı Kasım ayında Paris'te ve 2016 yılı Mart ayında Brüksel'de gerçekleştirilen terör saldırıları sonrasında Avrupa'da göçmenlere karşı potansiyel terörist algısı hızla yayılmıştır. Bu algının yayılması da maalesef islamofobi akımını da tetiklemiştir. 
Bu mülteci sorunu ve devamında gerçekleşen terör eylemleri, Avrupa Birliği’ni bir dizi önlem almaya zorlamıştır. Başta aşırı sağ partiler olmak üzere milliyetçilik maskesi altında bu durumu bahane ederek seçim malzemesi yapmaları, mültecilerin tekrar ülkelerine gönderilme seçeneğini güçlendirmiştir. Aslında en önemli sonucu ise; ülke sınırlarının yok olduğu AB ülkelerinde iç sınırların tekrar çizilmesi ve buralarda hem sınır kontrollerinin yapılması hem de gerek görüldüğü durumlarda sınırların geçişlere kapatılması, Avrupa Birliği'nin varoluş ruhuna aykırı olarak, insanların serbest dolaşımı konusundaki amaca aykırı davranmak durumunda kalmışlardır.

İlk zamanlar kısa süreli ve geçici olarak görülen mülteci konusunun, zamanla kalıcı bir hal alması sonucu, diğer bir ifadeyle Kirişçi (2014)'nin belirttiği üzere; sürekli büyüyen Suriyeli mülteci popülasyonu Türk toplumunu ekonomik, sosyal ve elbette siyasi bakımdan etkilemektedir.

Arap Baharı sürecinde Suriye'de meydana gelen olaylar nedeniyle göç akımının Türkiye'ye yönelmesi, ülkenin iç dinamiklerinde başta sosyolojik, ekonomik ve kültürel entegrasyon konusunda önemli gelişmeler yaşanmıştır. Başlangıçta 'misafir' olarak görülen ve tanımlanan Suriyeli mültecilerin durumu zaman geçtikçe 'uzun misafirliğe' dönüşmüş, bu da toplumun Suriyelilere olan bakış açısını olumsuz etkileyerek, neredeyse AB ülkelerinde aşırı sağ partilerin damgalayıcı sözlerini onaylarcasına duyumların yayılmasına neden olmuştur.

Ayrıca, zorunlu göçü ortaya çıkaran çatışma ve iç savaş koşullarının ortadan henüz kalkmadığı dikkate alındığında, söz konusu etkilerin uzun dönemde artarak devam edebileceği değerlendirilmektedir (Vural, 2017: 237). Kimi uzmanlara göre de bu etkilerin en az 10 yıl daha devam etmesi beklenmektedir (Dinçer, Karaca ve Yavuz, 2013). Bu olumsuz kanaatlerin ortadan kaldırılması konusunda kültürlerarası duyarlılığı artıracak çabalara ihtiyaç duyulmaktadır (Yıldırım, Aykaç, Okçu, 2019: 55).

Bu çalışmada, Suriye'de yaşanan gelişmeler 1şığında, Türkiye'ye giriş yapan Suriyelilerin hukuki statülerine yer verilerek, yarattıkları güvenlik riskleri ele alınacak ve ayrıca, ötekileştirme ve dışlanmışlık kavramları ışığında Türkiye'de bulunan Suriyeli sığınmacıların asayiş suçlarına karışma verileri doğrultusunda değerlendirmelerde bulunulacaktır.

\section{GÖÇ KAVRAMININ ANALIZİ ve TÜRKIYE'DEKİ DURUM 1.1. GÖÇ OLGUSU}

Maslow, ihtiyaçlar piramidini oluştururken insan davranışlarının temelinde, ihtiyaçların olduğunu belirlemiştir. Maslow 'un ortaya koyduğu piramidin en önemli özelliği ise sirasıyla yer alan 'Fizyolojik İhtiyaçlar', 'Güvenlik İhtiyaçları', 'Ait Olma ve Sevgi İhtiyaçları', 'Takdir ve Saygı İhtiyaçları', 'Kendini Gerçekleştirme' olgularının arasında hiyerarşik bir yapı olduğunu, alt basamaklardaki ihtiyaçlar karş1landıkça bir üst sekmeye geçişin mümkün olmasıdır. Yani insanlar temel ihtiyaçlarını karşıladıktan sonra diğer ihtiyaçlarını karşılama yoluna giderler (Küçükdoğru, 2011: 33-34). Buna göre, insanoğlu fizyolojik ihtiyaçların karşılanması durumunda, piramidin bir üst sırasındaki güvenlikli ortamda yaşama arzusunu gerçekleştirebilme güdüsüne yönelmesiyle alakalı olarak, göç kavramı burada karşımıza çıkmaktadır.

Ayrıca buna paralel olarak, insanoğlunun var olduğu ilk zamanlardan günümüze, ihtiyaç piramitleri doğrultusunda dünya üzerinde çok farklı bölgelere göç etmişler ya da göç etmek zorunda kalmışlardır. Bu göçler; açlık, kıtlık, doğal kaynaklar, doğal afetler, iklim, savaş, güvenlik, terör, kan davası vb. nedenlerle çoğu zaman gerçekleşmiştir. 
Görüldüğü üzere göç nedenlerinin gönüllü ve zorunlu olarak ayrıştığını görmekteyiz. Gerçekten de ekonomik anlamda kazanımlar elde etmek, fiziki ortamların daha uygun hale getirilmesi amaçlı, yani insansal olanakların gerçekleştirilebilmesi amacıyla yaşam koşullarının iyileştirilmesi için içten gelen bir istek doğrultusunda olan göçü gönüllü göç olarak tanımlayabiliriz.

Dış etkenlerden kaynaklanan nedenlerle daha güvenli bölgelere erişmek amaçlı olan göçe zorunlu göç diyebiliriz.

İçişleri Bakanlığı Göç İdaresi Genel Müdürlüğü, göç kavramını; 'uluslararası bir sınırı geçerek veya bir devlet içinde yer değiştirmek' olarak (Göç İdaresi Genel Müdürlüğü, 2019), Birleşmiş Milletler Nüfus Bürosu ise göçü; "kişinin köken yerinden başka bir yere giderek orada kalıcı yerleşmesi ve böylece ikamet yerinin değişmesi” şeklinde tanımlamıştır (UNCHR, 2015).

Dolayısıyla süresi, yapısı ve nedeni ne olursa olsun insanların yer değiştirdiği nüfus hareketleri olarak tanımlanmakta (Kaypak ve Bimay, 2016: 88) ve bu tanımın içerisinde mülteciler, yerinden edilmiş, yerinden çıkarılmış insanlar ve ekonomik göçmenlerde dâhil edilmektedir.

$\mathrm{Bu}$ bilgiler 1şı̆̆ında göç olgusunu en geniş haliyle; belirli bir bölgede yaşayan insan popülasyonunun, tamamının veya bir kısmının, gönüllü veya zorunlu bir şekilde, geçici veya kalıcı olarak başka bir bölgeye yerleşmek üzere yaşadığı bölgeden ayrılması olarak tanımlayabiliriz.

Yukarıda yapılan tanımdan hareketle Suriyeli mültecilerin, ülkelerinde yaşanan iç savaşlar neticesinde, hayat ve gelecek kaygıları yüzünden, zorunluluk esasına dayanarak göç etmelerini, zorunlu göç bağlamında değerlendirmeliyiz.

\subsection{GÖÇMEN KAVRAMI ve HUKUKİ OLARAK KAPSAMI 1.2.1. Göçmenlik Olgusu}

Küreselleşme ile birlikte değişen dünyada gerek iletişimin gerek ulaşımın gerekse de teknolojinin çok hızlı ve kolay bir şekilde yayılması, dünyanın "küçük bir köy" olarak tanımlanmasına neden olmuştur. Bu hareket edilebilirlik insanların daha kolay bir şekilde göç edebilmelerini teşvik etmiştir.

Hem zorunlu hem de gönüllü olarak göç eden insanların, bu zamandaki yolculuklarının daha kolay olması konusunda, Ünal (2014), içinde yaşadığımız dönemi bir "göç çağı" olarak nitelendirmiştir.

Göçmen: en basit tabirle, siyasi, ekonomik vb. saiklerle göç ederek yaşadığı ülkesini değiştiren insanı ifade etmektedir. Kısa süreliğine ülke değiştirmek göç olarak adlandırılmamakla birlikte, OECD göçmen olarak tanımlanabilme süresini bir sene olarak belirlemiştir.

Birleşmiş Milletler tarafindan 2017 yılında yayımlanan Uluslararası Göç Raporu incelendiğinde; "2000 yılında dünyada uluslararası göç hareketlerine 173 milyon kişi katılırken bu rakam 2010 yılında 220 milyona ve 2017 yılında ise 258 milyona ulaştığını görmekteyiz. Bunların yaklaşık \% 57'sine gelişmiş kuzey ülkeleri, \% 43'ü gelişmekte olan güney ülkeleri ev sahipliği yapmaktadır. Dünya çapında uluslararası göçmenler toplam dünya nüfusun \% 3,4'ünü oluşturmaktadır. Bu durum 1990'da \% 2,9 olarak gerçekleşmiştir. 1990-2017 yılları arasında, dünya genelindeki uluslararası göçmen artışının büyük bir bölümü, yıllık ortalama 5,6 milyon uluslararası göçmen ile 2005-2017 arasında gerçekleşmiştir. Yine aynı rapora göre, tüm uluslararası göçmenlerin toplam sayısının \% 60'ına Asya ve Avrupa'da ev sahipliği yapılmaktadır. Bunların yaklaşık 80 milyonu Asya'da, 78 milyonu Avrupa'da yaşamaktadır. Kuzey Amerika kıtası ise 58 milyon uluslararası göçmen ile üçüncü en büyük sayısını 
barındırmaktadır. 1990-2017 yılları arasında uluslararası sayıdaki en büyük göçmen artışı 31 milyon ile Asya'da görülmektedir" (UN, 2017).

Dünya genelinde toplamda 25,9 milyon sığınmacı bulunmakta ve bunun 3,6 milyonunu Türkiye'de bulunması, en çok sığınmacıya sahip ülke durumuna getirmiştir.

\subsubsection{Göçmen Statüsünün Hukuksal Boyutu}

Mültecilerin göç ettiği yeni ülkelerin sorumluluklarını belirleyen ilk hukuki belge, 1951 tarihinde oluşturulan ve 1967 tarihinde Ek protokolle desteklenen "Mültecilerin Statüsüne İlişkin Sözleşme”, yani Cenevre Sözleşmesi’ni, Türkiye imzalamış ancak Ek protokole coğrafi sınırlama şartı ile taraf olmuştur.

Türkiye tarafından konulan coğrafi sınırlama çekincesiyle, sadece Avrupa'dan gelecek kişileri mülteci olarak kabul edeceğini beyan etmiştir.

Cenevre Sözleşmesi'ne taraf olan devletler, mülteci statüsünü kazanmış olan kişilere oturma izni, çalışma izni ve hatta vatandaşlık kazandıracak kadar geniş bir yelpazede haklar tanımaktadir.

Cenevre Sözleşmesi, bir kişinin mülteci sayılabilme ölçütlerini belirlemiştir. Bu ölçütler: ırk, din, tabiiyet ve siyasi düşünceleriyle belli bir toplumsal gruba mensup olma; zulme uğrayacağından haklı sebeplerle korkma; vatandaşı olduğu ülkenin dışında bulunma; ülkesinin korumasından yararlanamama veya korku nedeniyle yararlanmak istememe; vatansiz olma ve yaşadığı ikamet ülkesine dönememe veya söz konusu korku nedeniyle dönmek istememe şeklindedir.

Bunlara rağmen Türkiye'nin müktesebatında, göçmenlerin statüleri hakkında herhangi bir yasal düzenleme bulunmamaktaydı. 2013 yılına kadar Bakanlar Kurulu Kararnamesi ve bazı durumlarda özel kanunla belli ülkelerden gelenlerin göçmen kategorisi içerisine alındıkları görülmektedir. İllegal olarak Türkiye'ye giriş yapmış kişiler kaçak olarak adlandırılmaktaydı (Başak, 2011, 5). Sığınmacı kavramı ise yukarıda belirtilen şartlar oluştuğunda mülteci olarak kabul edilen kişinin başvuru sürecindeki statüsüdür.

2013 yılında çıkarılan 6458 sayılı Yabancılar ve Uluslararası Koruma Kanunu (YUKK) ile mültecilik statüsüne açıklık getirilmiştir. Bu Kanun ile yabancıların Türkiye'ye girişleri, Türkiye'de kalışları ve Türkiye'den çıkışları ile Türkiye'den koruma talep eden yabancılara sağlanacak korumanın kapsamına ve uygulanmasına ilişkin usul ve esasları ve İçişleri Bakanlığına bağlı Göç İdaresi Genel Müdürlüğünün kuruluş, görev, yetki ve sorumluluklarını düzenlemek amaçlanmaktadır.

YUKK madde 91 gereğince çıkarılan “Geçici Koruma Yönetmeliği” ile Türkiye'nin Cenevre Sözleşmesi'nde koyduğu coğrafi çekince kısıtlamasına yönelik getirilen "geçici koruma statüsü” sayesinde, Suriyeli sığınmacıların Türkiye'de mülteci olabilme haklarının önü açılmış, bu yöndeki yasal boşluklar böylece giderilmiştir. Ayrıca Cenevre Sözleşmesi'nde mülteciyi tanımlayan "bireysel" durumu kapsayacak şekilde "kitlesel" kaçışlar deyimi de aynı yönetmelikte geliştirilmiştir.

Geçici koruma rejimleri, kısa sürede kitlesel bir akın halinde sınırlara gelen veya geçen kişiler için, devletlerin bireysel mülteci statüsü belirleme kapasitelerinin zorlandığı durumlarda ilan ettikleri bir uluslararası koruma çeşididir. Örneğin 1990'larda Kosova ve Bosna krizleri gibi mülteci krizleri sırasında da birçok Avrupa devleti tarafından ilan edilmiş ve kullanılmıştır (Ağır ve Sezik, 2015: 6). 
Bu yönetmelik sayesinde, Türkiye'ye zorunlu olarak gelen Suriyelilerin tamamı Türkiye'de kalabilmektedir. Bu yönetmeliğe kadar, Türkiye'de bulunan sığınmacıların durumu hükümet kararına bağlı olarak değişmekteydi. Bu yönetmelik sayesinde Suriyeli sığınmacıların yasal ve net bir statüye sahip olduklarını söyleyebiliriz.

Sonuç olarak Geçici Koruma Yönetmeliği ile Türkiye, Suriye uyruklu yabancıların ülke topraklarına şartsız olarak kabul edilmesini, geri göndermeme ilkesinin uygulanmasını, illegal olarak ülkeye giriş yapanların cezalandırılmamasını ve Türkiye'ye sığınan yabancıların temel ihtiyaçlarını karşılayacağını taahhüt etmiştir.

\subsection{KÜRESEL GÖÇLER ve TÜRKIYYE}

Arap Baharı süreci sonrasında Suriye'de meydana gelen iç savaştan kaçan mültecilerin dramları hala gözler önündedir. Gerek Soğuk Savaş dönemi sonrasında gerekse de Dünya Savaşları sonrasında, ortaya çıkan kaos sonrasında uluslararası zorunlu göçler yaşanmış, yarattığı ekonomik, sosyal, siyasal ve kültürel etkiler sonucu doğu-batı veya güney-kuzey algısı hissedilir hale gelmiştir.

Türkiye, göç konusunda Ortadoğu ülkeleri nazarında göç alan ve AB ülkelerine açılan önemli kilit ülke konumundadır. Bu yüzden göç ve göçmen sorunu, küresel göç hareketlerine koridor olan Türkiye'de de önem verilen konuların başında gelmektedir. Türkiye'nin jeopolitik konumu gereği, göç konusunda hem geçiş bölgesi hem de yerleşme alanı olarak düşünülmektedir. Gerçekten de Türkiye, Suriyeli mültecilerin yanı sıra birçok ülke sığınmacılarına ev sahipliği yapmaktadir.

Küresel göçün etkilerinin ağır olmasının ve sayısal olarak insan yoğunluğunun nedeni küreselleşme sürecidir. Çünkü bu süreçte çok sayıda insan, mülteci veya mağdur sıfatı ne olursa olsun çok çabuk etkileşim içine girebilmektedir.

Küresel göç konusu, başta batılı ülkeler olmak üzere her daim dünya gündeminde yer almakla birlikte, küresel göçün sonuçları olarak karşımıza çıkan sosyolojik, ekonomik, siyasi, insani vb. çıktıları ne yazık ki sebeplerinden daha çok tartışılmaktadır.

Suriye iç savaşının baş gösterdiği 2011 yılından bugüne kitlesel ve zorunlu göç hareketleri devam etmiş, başta sınır ülkesi olan Türkiye olmak üzere tüm Ortadoğu ve $A B$ ülkelerine etkileri yayılmış, ilgili ülkelerin ekonomik ve sosyal dinamiklerini de etkilemiştir.

Türkiye'de 3.649.750 kişinin mülteci olarak yaşadığı düşünüldüğünde, sosyal hayatta dışlanma, ayrımcılık, ötekileştirme, rrkçılık, yabancı düşmanlığ 1 , kayıt dışı yaşama ve çalışma, yoksulluk gibi sorunlar görülebilmektedir.

Türkiye'deki Suriyelilerin sayısının nüfusa oranı \% 4,3 civarındadır. Buna bağlı olarak, meydana gelen göçmen hareketlerinin Türkiye'de sosyal, ekonomik, siyasi, kültürel ve demografik sonuçlarının ortaya çıkması kaçınılmazdır (Ünal, 2014: 71).

Buna paralel olarak, yukarıda sayılan kitlesel göçün görülen olumsuz sonuçlarıyla en çok uğraşacak olan veya uğraşan Türkiye tedbirlerini hızlı bir şekilde almalıdır. Bu çalışmada muhtemel ortaya çıkabilecek olumsuz sonuçlardan bahsedilecek olup, konunun suça etkisi üzerinde çıkarımlar yapılacaktır.

\subsubsection{Türkiye'deki Suriyeli Sığınmacıların Genel Durumu}

Suriye'ye komşu ve çevre ülkelerin barındırdıkları Suriyeli mülteci sayılarına baktığımızda; Türkiye'nin Lübnan, Ürdün, Irak, Mısır ve Kuzey Afrika'da bulunan Suriyeli sığınmacıların daha fazla sığınmacıyı konuk ettiğini, sayılan bu ülkelerde bulunan toplam Suriyeli mülteci 
sayısına bakarak \% 64'lük gibi büyük bir oranın Türkiye'de koruma altına alındığını söyleyebiliriz.

Göç İdaresi Genel Müdürlüğü'nün 2019 Ekim ayı verilerine baktığımızda; Türkiye'de Suriyeli sığınmaciların en fazla bulunduğu il 549.405 kişi ile İstanbul'dur. İstanbul'u Gaziantep (451.466), Hatay (440.563), Şanlıurfa (428.929), Adana (239.518), Mersin (204.291), Bursa (177.229), İzmir (146.818), Kilis (116.749) ve Konya (109.679) takip etmektedir. Çalışmamıza esas olan Batman, 22.374 kişi ile Türkiye' nin en fazla Suriyeli sığınmacı bulunduran 20. ilidir.

\subsubsection{Göçmen Yardımları ve AFAD}

AB Komisyonu, insani amaçlara yönelik çalışan çeşitli uluslararası hükümet dışı örgütler aracılığı ile çatışma bölgelerindeki milyonlarca ihtiyaç sahibi insana yiyecek, içme suyu, barınma, tıbbi tedavi ve korumayı kapsayan hayat-kurtaran yardımlar sağlayarak insani programlara destek vermektedir (Aşkar, 2017: 139). AB, Suriye içinde zor koşullarda yaşamaya devam eden Suriyeliler ve bölgede Suriyeli mültecilere ev sahipliği yapan Lübnan, Ürdün, Irak ve Türkiye gibi komşu ülkelere yardım ve iyileştirme amaçlı 5 milyar avroyu aşan miktarda finansal destek gerçekleştirmiştir (ECHO, 2016). İlaveten AB, Türkiye'ye Şubat 2016'da 3 milyar avro yardım sözü vermiştir. Buna rağmen Suriyeli sığınmacılar için kullanılacak bu paranın çok az bir kısmı Türkiye'ye verilmiştir.

AB'nin Suriyeli mülteciler krizini çözme konusundaki kararlılı̆ğ, maddi yardım yapmanın ötesine geçememiştir. AB ülkelerinin gerek ekonomileri gerekse popülasyonları göz önüne alındığında, mülteciler konusunda potansiyelleriyle orantısız olarak mülteci akımı konusunda imkânlarının çok altında istihdam oluşturmuşlardır. AB ülkeleri, çok az sayıda Suriyeli sığınmacılara kapılarını açmışlardır.

Türkiye'de AFAD Başkanlığı koordinesinde, kamplarda yaşayan Suriyeliler için her türlü hizmet ve imkân seferber edilmiştir. "Barınma merkezlerinde, market, ısınma, güvenlik, ibadet, altyap1, haberleşme, itfaiye, tercümanlık, psiko-sosyal destek ve bankacılık hizmetleri de verilmekte olup, misafirlerin çamaşırhane, bulaşıkhane ve duş ihtiyaçları da karşılanmaktadır. Barınma merkezlerinde insani ihtiyaçların dışında Suriyeli misafirlerin sosyal ihtiyaçlarına yönelik eğitim ve mesleki kurs faaliyetleri de yürütülmektedir. Dinlenme merkezleri, çocuk ve oyun parkları, televizyon odaları ve internet hizmetleriyle Suriyeli misafirlerin boş zamanlarını değerlendirmeleri sağlanmaktadır. Türkiye Cumhuriyeti, Suriyeli sığınmacilara sunduğu yüksek standartlar bakımından; BM başta olmak üzere uluslararası camiada öncü ve model bir ülke konumuna ulaşmıştır" (AFAD, 2015).

AFAD' ın 2018 yılı Ekim ayı verilerine göre; Geçici barınma merkezlerinde yaşamlarını sürdüren toplam 174.256 Suriyeli, 10 ilde kurulmuş olan çadır kent ve konteyner kentlerde misafir edilmektedir. Geçici barınma merkezleri Hatay'da 4, Gaziantep'te 4, Şanlıurfa'da 4, Kilis'te 2, Mardin, Kahramanmaraş, Osmaniye, Adiyaman, Adana ve Malatya'da 1'er olmak üzere toplam 20 adettir (www.afad.gov.tr, 1.10.2018).

Türkiye'nin açık kapı politikası sonucu misafir olarak kabul edilen Suriyelilerin bir kısmı, yukarıda bahsettiğimiz kamplara yerleştirilmiş, geriye kalan büyük kısmı ise başta İstanbul, Gaziantep, Hatay, Şanlıurfa, Kilis olmak üzere ülke geneline dağılmışlardır.

\section{GÖÇÜN SORUNSALLIĞI ALGISI} 2.1. ÖNYARGI ve ÖTEKILEŞTIRME

Önyargılar kısaca haksız davranışlar bütünü olarak yorumlanmakta, kafalardaki önyargıların değişmesi çok zor ve uzun zaman almaktadır. 
Anderson (2015), boyutu ne olursa olsun "ulus sınırlı olarak hayal edilir. Hiçbir ulus kendisini insanlığın tümü ile örtüşüyor olarak hayal etmez" ifadesi ulusal kimliğin yaratılması konusunda her zaman başka bir "öteki" nin bulunduğunu belirtmektedir. Yani, yaratılan "öteki” insanlar azınlık, diğerleri çoğunluğu ifade etmektedir.

Buradan yola çıkarak azınlıkta bulunan insanları "yabancı" veya "mülteci” olarak, çoğunluğu da "milliyetçi yerel halk" olarak sınıflandırabiliriz.

"İnsanlar tarih boyunca başlarına gelen kötü olayların sebebini anlamaya ve anlam veremedikleri olayların da sorumlusunu bulmaya koyulmuşlardır. Birçok kültürde, günahların bir varlıktan başka bir varlığa aktarılabileceğine inanılmıştır. Bu nedenle toplumdaki kötülükleri ve günahları temizleme aracı olarak çeşitli varlıklar, hayvanlar ya da insanlar günah keçisi olarak seçilmişler ve toplumun arınmasını sağlamışlardır. Şeytanın icat edilmesinden sonra ise bireyleri kötülük yapmaya yönlendiren şeyin şeytan olduğu sonucuna varıldı ancak şeytanın somut olarak algılanamayan bir varlık olmasından ötürü içine girmiş olabileceği bedenler veya şeytanın işbirlikçileri aranmaya başlandı" (Arıcan, 2019: 27). Günah keçisi ilan etme ihtiyacı ulus-devletlerde de devam etti (Kearney, 2018, s. 49).

Buna paralel olarak düşündüğümüzde, ortak kültür, dil vb gibi, ortak kimlik paydaşında temel olan unsurlarda "bir" olmak konusunda, bu yapıyı bozacak/bozabilecek her türlü farklılık, ötekileştirme güdüsü içerisinde, toplumdan atılmaya ve dişlanmaya çalışılır. Toplumdan dışlanma ve yok edilme amacı sadece yabancılara özgü değil, aynı zamanda devlet düzenini bozan/bozmaya çalışan herkesçe bu gaye amaç edinilmiştir.

\subsection{SURIYELİ SIĞINMACILARA YÖNELİK ÖNYARGI ve ÖTEKILLESTTIRMEYİ TETIKLEYEN ETMENLER}

\subsubsection{Uzun ve Belirsiz Misafirlik}

Suriyeli mağdur insanların, iç savaş sonrasında insansal olanaklarını yerine getirmek amacıyla hayatta kalabilmek zorunlu olarak göç etmeleri sonucunda Türkiye'ye kitlesel olarak giriş yapmalarıyla, ortaya çıkan diğer bir problem statüleri olmuştur.

1951 Cenevre Sözleşmesi'nin coğrafi çekince ile ilgili maddeleri nedeniyle epey bir süre sığınmacıların statüleri netlik kazanmamıştı. Ortaya çıkan hukuki boşluk 22 Ekim 2014 tarihli Geçici Koruma Yönetmeliği’yle doldurularak “geçici koruma statüsü” verilmiştir.

Suriye'de yaşanan insanlık dramlarının yakın zamanda son bulacağı, rejimin değişeceği ve sonrasında Suriyelilerin ülkelerine geri döneceği beklentisi nedeniyle "misafir" olarak tanımlanmıştır. Ancak rejimin değişmemesi, insanlık dişı muamele ve zulümlerin devam etmesi daha çok sayıda Suriyelinin Türkiye'ye geçmesine neden olmuş, öngörülemeyen ve beklenmeyen bu gelişmelerin yaşanması statülerini "uzun misafirlik" ve hatta "komşu" statüsüne çevrilmiştir.

Kaya'nın 2016 yılında yaptığ 1 anket çalışmasında, İstanbul'da yaşayan Suriyelilerin \% 99'unun İstanbul'da kalma yanlısı olduklarını, sadece \% 1'inin İstanbul dışında ya da Türkiye dışında yaşama, AB ülkelerine gitme yanlısı, heveslisi oldukları şeklinde sonuçlar çıkmıştır (Kaya, 2016:10).

Misafirlikteki süre hala net olmamakla birlikte, zaman olarak kimi kaynaklarda Suriye'deki savaşın biteceği tarih kastedilmektedir. Misafirliğin uzaması şüphesiz ev sahibinde psikolojik olarak yabancı algısının daha belirgin olmasına, özel sınırlarının daha belirginleşmesine neden olmaktadır 
Bu bağlamda, Suriyeli mültecilerin Türkiye'de geçici misafir mi yoksa kalıcı komşu mu oldukları noktasında statülerindeki belirsizlik, yerel vatandaşların kafasında hala soru işaretleri olarak yer edinmiştir. Geleceklerindeki belirsizlik durumu zaman zaman yersiz ekonomik alandaki kaygılar ve dijital basının etik dışı yaptığı haberlerle birleşince ötekileştirme olgusu ortaya çıkmakta, bununla beraber Suriyelilerin Türkiye'den geri gönderilmesi gereken yabancılar olarak görülmelerine yol açmaktadır.

Karadağ'ın (2014) çalışmasında, yabancı algısının dışlanma eğilimlerini de geliştirdiği yönündeki tespitleri aslında misafirlikten komşu statüsüne geçmeye başladığı varsayılan Suriyeli mültecilere yönelik geliştirilen dışlanma duygusunun oluşmasını göstermektedir.

Suriyeliler karşılaştığı sosyal dışlanmışlık hissi neticesinde bazı kimlik bunalımları yaşamaktadır. Suriyeli sığınmacıların sahip olduğu kültürel farklılıkların çeşitli uyum sorunlarına neden olduğunu söylemek mümkündür. Zaman zaman günlük hayatta yerel vatandaşlar ile Suriyeli sığınmacılar arasında çeşitli anlaşmazlıklar gözlemlenebilmektedir.

Suriyeliler hakkında yerel halk tarafından oluşturulan toplumsal önyargılar, artan terör eylemleri ve uzun misafirlik sonucu değerlerini yitirmeye başlamaktadırlar. Türkiye'de uyum sorunu bu evrede ortaya çıkmaktadır. Yapılan çalışmalarda Suriyelilerin ülkede kalmasının büyük sorunlara yol açacağını düşünenlerin oranı $\% 76,5$ gibi yüksek bir orana ulaştı̆̆ gözlemlenmektedir. Buna ilaveten halkın yalnızca \%20'si Suriyelilerin Türkiye'ye uyum sağlayacağını düşünmektedir (Demir, 2015: 7). Başka bir araştırmada ise, Suriyelilerin uyum sağlayamayacağını düşünenlerin oranı \%66,9'dur (Erdoğan, 2014: 45).

Hatta daha ileriye gidilerek, son dönemde Suriyeli sığınmacıların "vatan haini" olarak nitelendirilmişlerdir (Doğanay ve Keneş, 2016: 177). Sığınmacı mültecilerin sosyal hayattaki entegrasyon sorunlarını en aza indirgemek, artan toplumsal önyargının ve duyusal çatışmanın önüne geçmek adına ötekileştirici popülizm söylemlerinden kaçınılmalı ve gerekli tedbirler alınmalidir.

Suriyeli göçmenlerin hayatta kalma arzusu için yurtlarını terk ettiklerini, Türkiye'nin tek gayesi ev sahibi olarak yardım eli uzatıp yaraların acilen sarılmasını sağlamaktır. Unutulmamalıdır ki, mağdur olan bu insanların \% 30' u hâlihazırda devam eden iç savaşta en az bir yakınını kaybetmiştir. Çoğu Suriyeli sığınmacı ciddi psikolojik sorunlar yaşamakta, bir şekilde şahit olduğu şiddetin izlerini taşımaktadır (AFAD, 2013: 32). Zor günler geçiren bu insanlar açısından da psikolojileri ve hassasiyetleri iyi anlaşılmalı, hem yetişkinlerin hem de çocukların entegrasyonuna önem verilmelidir. Sığınmacı çocuklar hem ülkelerindeki savaşın hem de çocuk yaşta göçmen sıfatı kazanmalarının mağdurudurlar. Sayıları nesil denilebilecek kadar çok olduğundan gerekli eğitim imkânları yaratılarak, kayıp nesil yetiştirmenin önüne geçilmelidir.

Entegrasyonun hızlandırılabilmesi için sosyal hayat düzenine mümkün olduğunca dâhil edilmelidirler. Gerek kamu makamlarınca gerekse de STK'lar vasıtasıyla bu süreci destekleyici adımlar atılabilir. Barınma merkezlerinde veya çeşitli illerde yaşayan Suriyeli sığınmacılara psikolojik, kültürel destekler sağlanabilmelidir. Her durumda her alanda toplumsal benimseme sağlanmalı ve etkili entegrasyon politikaları oluşturulmalıdır.

\subsubsection{Basın ve Sosyal Medya Etkisi}

Kavimler göçü olarak da adlandırılan Suriyelilerin Türkiye’ye geniş kitlelerce gerçekleşen zorunlu göç sürecinin Türkiye'ye olan sosyal, siyasi ve ekonomik yansımaları bulunmaktadır. 
Bunun sonucunda göçmenlerle ilgili karşılaşılan bazı sorunlar, basın ve sosyal medya yoluyla hızla yayılmakta, geniş kitlelere ulaşan doğru-yanlış duyumlar göçmen karşıtlığ 1 konusunda aleyhte kamuoyu oluşmasina neden olmaktadır.

Medyanın dijital gücü de buna eklendiğinde, etkileşimin çok kısa sürede geniş kitlelere yayıldığını söylemek mümkündür. Online gazetecilik olarak da adlandırılabilecek bu gazetecilik anlayışı, günümüzde bilginin en kolay kaynağı olan internet teknolojisini kullanmakta ve enformasyona 24 saat aralıksız erişme imkânı tanımaktadır. Gerek dijital medya gerekse de yazılı basının üzerine düşen en önemli görev; toplumda önemli bir gerginlik yaratmadan bütünleşmeyi sağlayacak bir biçimde çözümünde ise önemli bir farkındalık yaratma ve kamuoyu oluşturmaktır (Çambay, 2019: 164-166).

Buna bağlı olarak, gerek dijital medyanın gerekse de sosyal medya kullanıcılarının yoğun olması, mültecilerle ilgili yapılan/yapılacak olan doğru-yanlış haberler ve duyumlar, çok ciddi mecralara ulaşacağından oluşturulan önyargının kamuoyundan izlerini silmek çok kolay olmamaktadır.

Suriyeli mülteciler aleyhine oluşabilecek önyargılar nedeniyle popülizmin en büyük silahı olan azınlıkların ötekileştirilmesini gündeme getirmekte, dijital platformda mültecilere yönelik yapılan bu türlü haberler maalesef Suriyelilere yönelik tehdit algısı oluşturmakta, sığınmacılar üzerinde korku ve kaygı oluşturmaktadır. Bu durum silsile yolu ile tüm göçmenlere ve azınlık vatandaşlarına sıçramaktadır. Sosyal ve dijital medya okuryazarlığı bu denli önemli sonuçlara yol açmaktadır.

Büyük bir kamuoyu oluşturucu gücü bulunan dijital gazetelerde oluşturulan haberlerin her türlü ayrımcılıktan ve nefret söyleminden uzak olması ciddi önem taşımaktadır (Binark ve Bayraktutan, 2013: 88).

İnternet mecrasında yapılan paylaşımların veya haberlerin etik ilkeler göz önüne alınarak icra edilmesi hususunun gereği açıktır. Çünkü yukarıda bahsedildiği gibi, özellikle dijital basının ve sosyal medyanın ciddi derecede kamuoyu oluşturma gücü bulunmaktadır. Toplumsal algının sağlıklı inşa edilebilmesi için mültecilerle ilgili yapılacak haberlerde daha hassas ve özenli şekilde davranılmalıdır.

Nisan 2011 öncesinde sığınmacılar ve mültecilerle ilgili çıkan haberlerin çoğunun etik ilkelerle yapıldığı, özellikle gözetim altında tutuldukları yerlere ilişkin övgü yazılarının bulunduğunu söyleyebiliriz (Demirel, 2013: 469).

Nisan 2011 sonrasında, Çambay'ın (2019), Türkiye'de Suriyeli mültecilerin nasıl temsil edildiği ve toplumsal algının ne durumda olduğunu ölçmeyi amaçladığı çalışmasında, en çok ziyaret edilen gazetelerin internet sayfalarında 2017 yılına ait haberleri analiz etmiş, sonuçlar doğrultusunda 104 adet Suriyeli mülteciler aleyhinde habere rastlanmıştır. Yine aynı çalışmada, Suriyelilerin toplumsal huzur, refah ve düzeni bozan, kaçakçılık, yasadışılık gibi kanuni olmayan yollara başvuran, işsizliği artıran, düşük ücrete neden olan, hayatı tehdit eden bir kesim olarak öne çıkartıldığ 1 bu bağlamda da sorunlu bir biçimde temsil edildikleri dikkat çekmektedir. Bunlara ek olarak Suriyeli mültecilere yönelik en olumsuz temsil biçimi olarak güvenlik tehdidi yaratan, toplumsal barış ve huzuru bozan, uygar olmayan bu sebeple de geleceğe yönelik umutsuzluk yaratan Suriyeli imgesi dikkat çekmektedir.

Maalesef Türk basınında yer alan dijital platformdaki haberlerde Suriyeli sığınmacılarla ilgili çıkan ayrımcı ve nefret söylemleri içeren haberler görmekteyiz. Bu da toplumsal birlik beraberlik bağlamında sorunlu, önyargılı, ayrımlaştırıcı ve ötekileştirici ilişkilere neden 
olmaktadır. Göçmenlerle ilgili haberlerde aşağılayıcı, küçük düşürücü ve hakaret içeren ifadelere yer verilmesi, ciddi toplumsal sorunlara yol açmaktadır (Kuş, 2016: 101).

Ahlaki panik yaratacak şekilde, ırkçılığın ve yabancı düşmanlığının hortlamasına neden olan söylemlerle donatılmış, teyit edilmemiş duyumlarla desteklenmeye çalışılan bu haberler sonrasında sığınmacılara kaçak, yabancı, çete gibi etik olmayan söylemler yapıştırılmıştır.

Bunların yanında çok çeşitli çalışmalarda, görsel ve yazılı medyada çıkan haberlerin analizleri incelendiğinde yukarıdaki tespitlere paralel sonuçlar ortaya çıkmaktadır. Suriyeli sığınmacıları; sürekli huzuru bozan, mahalleliler tarafindan sevilmeyen, ayaklanmaya müsait, saldırgan tavırlar içinde bulunan, kavgacı, halk tarafindan geri gönderilmek istenen, çocuk çalıştıran, fuhuş, hırsızlık, gasp, dilencilik yapan, illegal çalışan, işsizliğe ve kira artışlarına neden olan, sosyal çevreye uyumsuz kimseler olarak lanse edilmektedir.

\subsubsection{Dünya'daki Aşırı Sağ Parti Söylemleri "Popülizm"}

Uluslararası Af Örgütü'nün, “Dünyada İnsan Haklarının Durumu 2016-2017” adlı raporunda, küresel manada politikaların ötekileştirme ve popülizm üzerinden oluşturulduğuna dikkat çekmektedir. Buna ilaveten siyasilerin toplumsal sorunların müsebbipleri olarak ötekileştirilen insanları göstermeleri, toplumsal kutuplaşmayı teşvik edici söylemlerde bulunmaları son derece zarar verici bir politikadır.

Gerçekten de küresel politikaya baktığımız zaman, ülkede meydana gelen ekonomik kriz, terör eylemleri, işsizlik gibi toplumsal, siyasal ve ekonomik sorunlarda, politikacıların faturayı mültecilere, azınlıklara veya dış güçlere kesmeleri süreklilik arz eden siyasi bir uygulamadır. $\mathrm{Bu}$ safhadan sonra ulus devlet ve milliyetçilik duygularının zayıfladığı tezi öne sürülür. Problemi yansıtarak hedef aldığı grup ötekileştirilir.

Hayatta kalma mücadelesi amacıyla yaşadıkları vatanlarını terk etmek zorunda kalan insanları, ülkesel tehdit olarak tanımlamışlardır. Bu durum $\mathrm{AB}$ ülke vatandaşlarınca daha yaygın bir durumdur. Türkiye'deki algıları çoğunlukla, sığınmacıların ve mültecilerin, sadece sınırın ötesinden gelen ve ulusal bütünlüğü tehdit eden 'yabanc1lar' değil, niyetleri belirsiz, göç etme gerekçeleri şüphe götürür 'tekinsiz' kişiler” (Aydın ve Oğuz, 2015: 303) şeklindedir. Türkiye'de sığınmacılar ve mülteciler, gerek basın organlarınca gerekse de halk tarafından kulaktan duyma bilgilerle maalesef ötekileştirilmektedir.

2016 yılında Trump'ın ABD Başkanı seçilme sürecinde ve yine aynı yıl Brexit referandumlarında, popülizmin ve kutuplaşmanın izlerini görmekteyiz. Brexit referandumu akabinde Fransa'da, Hollanda'da ve Avusturya'da hâkim olan aşırı sağ partiler ülkelerinin Avrupa Birliği'nden ayrılması için referandum çağrısında bulunmuşlardır. Trumpizm ve Avrupa popülizminin temelinde yer alan İslam düşmanlığ 1 sosyolojik uyum sorunlarından kaynaklanan ötekileştirmenin bir sonucu olarak ortaya çıkmıştır (Eren, 2017: 6). 11 Eylül terör saldırıları sonrasında ulusal güvenlik konusunun gündemine göçmen politikaları yerleştirilerek, ulusal güvenliğin ayrılmaz bir parçası durumuna gelmiştir.

11 Eylül sonrasında 2004 yılında Madrid'de, 2005 yılında Londra'da, 2014 yılından günümüze birçok Avrupa ülkesinde terör saldırıları gerçekleşmiş, bu saldırıların radikal terör örgütlerince üstlenilmesi sonucu, ne yazık ki dünyada islamofobi olgusu artmış, Müslümanlar küresel güvenlik tehdidi olarak görülmeye başlanmıştır.

Avrupa'da gerçekleşen İşi̇D terör örgütünün saldırıları sonucu; siyasiler halklarının korku ve endişelerini seçim malzemesi yaparak, Müslümanlara ve Müslüman mültecilere yönelik ötekileştirme üzerinden popülizm düşüncelerini seçim malzemesi haline getirmiş, aşırı sağ partilerin oy oranlarında gözle görülen artışlar kaydedilmiştir. 
2009'da İsviçre'deki aşırı sağ parti SVP, 2017'de Hollanda'da Geert Wilders'in liderliğindeki aşırı sağ parti PVV, Almanya'da PEGİDA hareketi, Avusturya'da aşırı sağ parti FPÖ başarılarını mülteci krizinden beslenmeye borçludur. Hatta meydana gelen terör saldırılarına karşın, AB'nin ruhuna aykırı olarak geçici süre Schengen' i askıya almış ve sınır kontrolleri uygulanmıştır.

2014 AP seçimlerinde de aynı etkileri görmek mümkündür. Burada da aşırı sağ tandanslı popülist partilerin oy oranlarında artışlar kaydedilmiştir. "Ulusal Cephe (FN), Bileşik Krallık Bağımsızlık Partisi (UKIP) ve Danimarka Halk Partisi (Dansk Folkeparti) oyların yaklaşık yüzde 25'ini alarak kendi ülkelerinde AP seçimlerinde en çok oyu alan parti olarak ön plana çıkmıştır. Aynı zamanda Hollanda'da Wilders'in partisi PVV, Finlandiya'da The Finns ve Avusturya Özgürlük Partisi (FPÖ) de AP seçimlerinde kayda değer başarılar elde etmiştir" (Eren, 2017: 12-13).

Sonuç olarak, göçmenler bulundukları ülkede hem adi suçların hem de terör suçlarının potansiyel failleridir. Dünya'da artan küresel terör olayları sonucu, göçmenlerin ülkelere kabul şartları ağırlaştırılmış, mevcut göçmenlerin ise ülkelerine dönmeleri konusunda aşırı sağ parti siyasileri başta olmak üzere ülkeler tarafından baskın politikalar izlenmiştir.

Küresel zorunlu göç hareketleri, göçe maruz kalan ülkelerde, ötekileştirmenin devamı olarak milliyetçilik söylemlerinin daha gür çıkmasına neden olmaktadır. Etnik kökenlerin ve kültürlerin geniş bir yelpazede bulunmasını, zenginlik olarak görmek istemeyen bu tür siyasetçiler, çoğunlukla aşırı sağ parti gruplarını bundan nemalandırmaya çalışarak, seçim malzemesi olarak görmektedirler.

\subsubsection{Sınır Güvenliği Sorunu}

Türkiye'nin Bulgaristan (269 km), Yunanistan (203 km), Gürcistan (276 km), Ermenistan (328 $\mathrm{km})$, Azerbaycan $(18 \mathrm{~km})$, Irak $(384 \mathrm{~km})$, İran $(560 \mathrm{~km})$ ve Suriye $(911 \mathrm{~km})$ kara sinırlar1 bulunmakta, 1762 kilometreden oluşan Karadeniz deniz sınırı ve 4768 kilometreden oluşan Ege ve Akdeniz deniz sinırları mevcuttur. Türkiye'nin AB'ye tam üye olması durumunda AB'nin dış sınırlarının büyük ölçüde genişlemesine sebebiyet verecektir (Küçükdoğru, 2019: 137). AB için önemli bir aktör olan Türkiye, jeopolitik konum avantajları nedeniyle göz ardı edilemeyecek bir ülkedir (Kaya, 2018:193).

Neredeyse yarım asra yakın bir süre boyunca Ortadoğu'da meydana gelen siyasi, sosyal, ekonomik ve sosyolojik sorunlar ve mezhepsel Türkiye'yi olumsuz etkilemektedir.

Saddam sonrası Irak'ta meydana gelen otorite boşluğu ve Suriye'deki kaotik durumun uzaması Türkiye'nin en uzun kara sınırı olan Suriye ile Saddam sonrası bir türlü devlet otoritesinin hâkim kılınamadığı Irak sınırlarında önemli güvenlik riskleri ortaya çıkmıştır (Ağır ve Sezik, 2015: 107).

Hükmedilemeyen bu bölgelerde türeyip palazlanmaya çalışan terör örgütleri, Türkiye'nin güvenliği açısından da risk teşkil etmektedirler. Bu bölgelere terör örgütleri daha kolay yerleşmekte, lojistik güç konusunda da problem yaşamamaktadır.

Terör örgütlerinin, ekonomik, siyasi ve sosyal sorunların bulunduğu bölgeleri, büyümeye elverişli ortamlar olarak seçtiği düşünüldüğünde, Suriye'deki iç savaşların mezhepsel ve etnik kökenden kaynaklı saiklerden çıktığı göz önüne alındığında, bu keşmekeş ortamın terör örgütleri açısından uygun bölgeler olduğunu, buralarda kendilerinin daha kolay kamufle edebildikleri, hatta kendilerini meşrulaştırmaya çalıştıkları görülmektedir. 
Türkiye, hem bu güvenliksiz bölgenin en stratejik çözüm ülkesi ve köprüsüdür hem de bununu sonuçlarından zarar gören ülkesidir.

Suriye'de rejim yönetimini destekleyenlerin, İran'ın, ABD'nin, batılı dış aktörlerin ve Rusya'nın bu bölgede askeri müdahalelerde bulunması, bölgenin çok aktörlü bir yapıya kavuşmasını sağlamıştır. Ağır ve Sezik'in (2015), Suriye'deki durumun tamamen vekâlet savaşlarına dönüştüğü tabiri çok yerindedir. Bloklaşarak taraf olan ülkeler, Rusya ve ABD yanlısı olarak ayrılmışlardır.

$\mathrm{Bu}$ ülkelerin Türkiye'nin yanı başında gerçekleştirdikleri müdahaleler, Türkiye'ye zarar vermektedir. Nitekim Türk hava sahasını ihlal eden Rus savaş uçağının 24 Kasım 2015'te düşürülmesinin karşılığı olarak, diplomatik ve uluslararası anlamda başta ekonomik ve turizm konusu olmak üzere Türkiye'ye ciddi yaptırımları ve yansımaları olmuştur.

\subsubsection{Terörizm Boyutu}

Sayıları 3,6 milyonu bulan Suriyeli sığınmacıların Türkiye'ye göç etmeleri sonucu bir takım güvenlik risklerini beraberinde getirmiştir.

Boulden (2009), İç savaş ile terörizm arasındaki bağlantı konusunda, iç savaşın terörizmin sebebi veya sonucu olabileceğine işaret etmiştir. Çeşitli kaynaklarda kavimler göçü olarak tabir edilen bu göç akımı şüphesiz terörizm boyutunu da canlandırmaktadır. Suriye'deki iç karışıklıktan nemalanan terör örgütleri, bu sayede daha rahat hareket ederek yer değiştirmekte, lojistik ve acil ihtiyaçlarına daha kolay ulaşabilmektedir. Bu sayede hâkimiyet alanlarını arttırmışlarıdır.

Burada kastedilen terör örgütleri, Suriye'deki iç savaş sonucu ortaya çıkan otorite boşluğundan nemalanarak, Türkiye'de çok sayıda terör eylemlerini gerçekleştirmişlerdir. Bu terör örgütlerinin; 2015'te Suruç'ta ve Ankara Garı'nda, 2016'da Kızılay Meydanı'nda, İstanbul Atatürk Havalimanı'nda ve Beşiktaş Stadı çıkışında, 2017'de İstanbul'da bir gece kulübünde gerçekleştirilen terör eylemleri, halk içerisinde infial yaratmıştır.

Türkiye'nin ulusal güvenliğini tehdit etmeye çalışan bu terör unsurlarının eylemleri nedeniyle, vatandaşlar arasında korku yayılmak istenmektedir.

Bunların ekonomik, siyasi ve sosyal sonuçları yadsınamaz niteliktedir. Sadece 2015 yılında turizm sektöründe yaşanan gelir kaybı yaklaşık \% 45 'tir.

Artan terör saldırıları ve sınır ihlalleri üzerine Türkiye "Fırat Kalkanı", "Zeytin Dalı" ve "Barış Pınarı" harekâtlarını gerçekleştirmektedir. Bu geniş katılımlı ve maliyetli harekâtların esas amacı Suriye'de kümelenmiş terör örgütlerini etkisiz hale getirmek ve sınır güvenliğini yeniden tesis etmeye çalışmaktır.

Suriye'deki otorite boşluğundan yararlanan terör örgütlerinin hedefi yukarıda örneklendirdiğimiz üzere sadece Türkiye değildir. Kaotik ortamda hızla büyüyen ve palazlanan terör örgütleri $\mathrm{AB}$ ülkelerinde de eylem yapmaktadır. Gerçekten de Suriye konusunu irdelediğimizde civar komşu bölge ülkelerinde ve $\mathrm{AB}$ üyesi ülkelerde görülen terör saldırılarının, Suriye'deki kaos sonrasında arttığını söylemek mümkündür.

2001'de ABD'de, 2015'te Paris'te ve 2016'da Brüksel'de yaşanan terör saldırıları Avrupa ülkeleri için de ciddi bir tehdit haline gelmiştir. Bu saldırıların sonucu olarak özellikle AB ülkelerinde güvenliği sağlamak amacıyla $\mathrm{AB}$ ruhuna aykırı (serbest dolaşım) olarak ek tedbirler alınmıştır. ABD'de ve $\mathrm{AB}$ ülkelerinde mülteci konusu tekrar gündeme getirilmiş, popülizmin öncülüğünde islamofobi yaygınlaştırılmaya çalışılmış, Müslüman göçmen karşıtllı̆ dillendirilerek aşırı sağ partilerin seçim malzemesi haline getirilmiştir. 


Year:4, Volume:4, Number:8 / Yul:4, Cilt:4, Sayı:8 / 2020

\subsubsection{Frontex ve İnsan Ticareti}

Avrupa Birliği, sınırların güvenliği konusunda, Avrupa Sınır ve Sahil Koruma Ajans1 FRONTEX' i bünyesinde kurmuştur. Görev ve yetkileri açısından esas amaçları son yıllarda yaşanan kontrolsüz yoğun mülteci akınından Avrupa ülkelerini korumak ve gündemde canlı tutulan Avrupa'ya geçmek isteyen mültecilerin bu yolda hayatlarını kaybetmelerinin önüne geçmektir.

Avrupa Birliği’nin sınırlarında güvenliğin artırılması yönündeki çalışmaları mülteci krizi ile başlamıştır. Avrupa'ya olan mülteci akının sonucunda da Almanya, Avusturya, Danimarka, İsveç ve Norveç'in gibi Schengen Bölgesi ülkeler artık göçmenlere karşı yeniden sınır kontrolü uygulaması başlatmışlardır (Küçükdoğru, 2019: 113).

Suriye'de meydana gelen iç savaşın Türkiye'ye verdiği zararlardan biri de insan ticareti suçlarındaki artıştır. Yukarıda bahsettiğimiz özelliği itibariyle Türkiye'nin yeri ve konumu, göçmen kaçakçıları için uygun ve müsait bir ülke haline getirmektedir.

Türkiye'nin Yunanistan ve Bulgaristan gibi AB ülkelerine komşu olması sınır bölgelerinde sorunlar yaşanmasına neden olmaktadır. AB ülkelerine veya Yunan adalarına geçmeye çalışan Suriyeli sığınmacıların bir kısmı sınırlar nedeniyle tehlikeli deniz yolunu seçmekte ve maalesef önemli bir kısmı hayatlarını kaybetmektedirler.

2014 yılında Ege Denizi'nde Yunanistan'a geçmek isterken ölen göçmen sayısı 69, 2015 yılında 279, 2016 yılında 192'dir (Sahil Güvenlik Komutanlığı, 2019). Türkiye'ye 1998-2016 arası dönemde kaçak giriş yapan göçmenlerin toplam sayısı 1.281.959 kişi olup, bunların yaklaşık \% 40’ 1 son 5 yılda gelmiştir (Göç İdaresi Genel Müdürlüğü, 2019).

Umuda yolculuk olarak adlandırılan bu süreçteki ölümlere rağmen göçmenlerin Avrupa hayalleri devam etmektedir. 2014 yılında denizde yakalanan kaçak göçmen sayısı 14.961, 2015 yılında 91.611, 2016 yılında 37.130'dür (Sahil Güvenlik Komutanlığı, 2017).

Yakalanan göçmen kaçakçısı sayıları da insan ticareti suçundaki artışı gözler önüne sermektedir. 2010'da yakalanan kaçakçı sayısı 1.711 iken bu sayı 2015'te 4.471'e ulaşmıştır. 2016 'da 3.314, 2017'de 4.641, 2018'de 6.278 ve 2019 yılı Ekim ayı itibariyle bu sayı 6.947'ye ulaşmıştır (Göç İdaresi Genel Müdürlüğü, 2019). Görüldüğü gibi kaçak göçmen geçişleri tüm uğraşlara rağmen durmamakta, Ege Denizi’nde insan ticareti her şeye rağmen sürmektedir.

\subsubsection{Ekonomik Sorunlar Algisı}

\subsubsection{1. "İşsizlik" ve "İstihdam" Korkusu}

Türkiye'de Suriyeli sığınmacılar, 15 Ocak 2016 tarihli “Geçici Koruma Sağlanan Yabancıların Çalışma İzinlerine Dair Yönetmelik” kapsamında çalışmalarına izin verilmiştir. Bu çalışma izni politikasına göre, işyerlerine \% 10 kota konulmuştur.

Suriyeli mültecilerin yasal olarak çalışma izni alabilmelerinde herhangi bir kısıtlama veya ağır şartlar bulunmamasına rağmen 2016 itibariyle 3 bin 800 kadar çalışma izni verildiği (Taşkın, 2016: 25), bu sayının çok sınırlı kaldığı gözlemlenmiştir.

Genel çerçeveden baktığımızda çalışan Suriyeli sığınmacıların çoğunlukla tarım, tekstil ve inşaat işçileri olduklarını, bazı Suriyelilerin üretici konumunda olduklarını, çok az bir kısmının ise doktor, avukat, öğretmen olduklarını söylemek mümkündür.

TÜİK (2019) verilerine bakıldığında, Türkiye'deki işsizlik oranının 2019 Temmuz ayı itibariyle \% 13,9 olarak belirlendiğini görmekteyiz. Türkiye'de işsizliğin hâlihazırda var olduğunu, bu oran içerisindeki Türk vatandaşlarının meslek seçimi yaptıklarını, iş beğenmeme durumundan 
kaynaklı dökümcü, kaynakçı, tekstil makinası operatörü gibi yaklaşık 170 bin istihdamın boş kaldığını Taşkın (2016) belirtmektedir.

Toplumdaki insanların çalışmak istemediği bu kadrolarda Suriyelilerin çalıştıkları görülmüştür. Bunlara rağmen Suriyelilerin yerli vatandaşların işlerini ellerinden aldıkları, düşük ücrette çalışmaya razı olmaları sonucunda ücretlerin düştüğü yönünde genel bir kanaat oluşmaktadır.

Gaziantep'te yapılan çalışmada katılımcıların \% 59'u Suriyelilerin işsizliğe neden olduklarını düşünmektedir (SABR-MDD, 2015: 21-23). Buna karş1lık Bahçekapılı ve Çetin (2015)'in çalışmalarına göre, göçmen akımıyla birlikte Malatya, Elazığ, Bingöl, Tunceli, Kilis, Konya, Gaziantep ve Adıyaman'da işsizliğin arttığını, sanayi üretiminin kümelendiği İstanbul, Bursa, Kocaeli, Gaziantep, Konya gibi illerde olumlu istihdam etkisinin görüldüğünü, bu sonuçlar ışı̆̆ında Suriyeli sığınmacıların işsizlik oranları üzerinde herhangi bir etkilerinin olmadıklarını belirtilmiştir.

\subsubsection{2. Ücretlerin Azalma Korkusu}

Türkiye'ye geçici koruma altına alınan Suriyelilerin büyük bir kısmının Türk vatandaşlarının çalışmak istemediği ağır ve zor şartlar altında icra edilen mesleklerin istihdamlarında yer aldıklarını belirtmiştik.

$\mathrm{Bu}$ nedenle Suriyeli mültecilerin emek piyasasında ucuz iş gücü talebini karşılamaktadırlar. Konu ile ilgili yapılan çalışmada Şanlıurfa'da halkın \%86'si, Gaziantep'te \% 84'ü, Hatay'da \% 78'i, Kilis'te \%54'ü ücretlerin düşmesinden Suriyelileri sorumlu tutmaktadır (Demir, 2015: 17).

Yapılan saha çalışmalarında Suriyeli işçilerin Türk işçileriden daha az ücret aldıkları ortaya konmuştur. Mutlu ve diğerleri (2018) çalışmasında Suriyeli işçilerin \% 46'sının, Türk işçilerin ise \% 20'sinin asgari ücretin altında çalıştıklarını ortaya koymuştur.

\subsubsection{Ekonominin Zayıflama Korkusu}

Türkiyeli işçiler arasında Suriyelilerin Türkiye'ye gelişinin ülke ekonomisine olumsuz etkide bulunduğunu belirtenlerin oranı yüksektir (Mutlu ve diğerleri, 2018: 86).

Buna karşın Türkiye'deki Suriyelilerin çoğunlukla tekstil, inşaat ve tarım gibi, Türk vatandaşlarınca tercih edilmeyen, ücret ve sigorta konusunda yetersiz ve güvencesiz olarak istihdam edilmekte, üretime katkı sağladıkları görülmektedir. Dolayısıyla Türk ekonomisinin büyümesine az da olsa etki etmektedirler.

Bunun yanında Türkiye'de, 2015 yılının sonunda Suriyeliler tarafından kurulmuş 4.000'e yakın firmanın bulunduğunu, bunlardan 600 civarı firma Gaziantep'te bulunmaktadır.

Yapılan çalışmalar, zorunlu göç sonucu nüfustaki \% 1'lik artışın, üretimi \% 1,2'lik düzeyde artırdığını ortaya koymaktadır (Vural, 2017: 246). Sonuç olarak zorunlu göçün Türkiye'de işsizlik oranlarına, üretime ve ekonomiye yararlar sağladığı, Türkiye'de işsizliği artırmadıkları gibi ücretlere de herhangi bir etkilerinin olmadığı aşikârdır.

\subsubsection{Barınma Merkezli Sorunsallar}

Suriye'den plansız olarak tahmin edilemeyen boyutta insanın alelacele Türkiye'ye kabul edilmesi, sığınmacıların acil ihtiyaçlarını giderebilmek ve yerleşmeleri noktasında hızlı hareket edilmiştir.

Kurulan barınma merkezleri sayesinde Suriyelilerin temel ihtiyaçları karşılanmaktadır. Kampta misafir edilen Suriyeliler sağlık ve eğitim hizmetlerinden ücretsiz olarak yararlanabilmektedir. Bunlara rağmen Türkiye’ye gelen Suriyeli sığınmacılardan sadece \% 10 civarının bu kamplarda 
yaşadıklarını, geriye kalan çok yüksek bir oranın ise sosyal hayatta kendi düzenlerini kurmaya çalışmakta olduklarını söyleyebiliriz.

\subsubsection{Eğitim Alanındaki Sorunsallar}

Unutulmamalıdır ki, okul çağında olup olmadıkları fark etmeksizin, tüm göçmen çocuklar hem ülkelerindeki insanlık dramının hem de göçün en büyük mağdurlarıdırlar.

Türkiye'de 2016 yılı itibariyle okul çağındaki Suriyeli çocuk sayısı 850 bin civarında olup bunların 325 bini, yaklaşık olarak yüzde 38'i okula gitmekte, geriye kalan 500 bin civarı çocuk halen eğitim almamaktadır. Okula giden 325 bin çocuktan sadece 65 bini Türk okullarına gitmekte ve Türk eğitim sistemi içinde Türkçe eğitim almaktadır. Geri kalan 265 bin çocuk ise Geçici Eğitim Merkezlerinde Suriye okul müfredatına göre Arapça eğitim almaktadır (Erdoğan, 2016: 37).

MEB verilerine göre, ülkemizde kamp içi 31, kamp dışı 401 olmak üzere 432 geçici eğitim merkezi bulunmaktadır. Geçici eğitim merkezlerinde Suriyeliler, kendi dilinde öğrenim görmektedirler. Ayrıca Türk öğretmenler tarafından haftada 15 saat Türkçe dersi verilmektedir (Yıldırım, Aykaç ve Okçu, 2019: 59).

2019 yılı Göç İdaresi verilerine göre; Suriyeli sığınmacıların yaklaşık \% 46,8' i 18 yaş altı çocuk statüsündedir. Sayısal anlamda neredeyse bir kuşağı temsil edebilecek bu çocuklara verilen eğitimin ve öğretmenlerin niteliği, mevcut okulların durumu, eğitim materyalleri, kısacası eğitimin kalitesi konusunu üzerine düşülmesi gereken önemli bir unsurdur.

Eğitimin, sığınmacıların toplumsal entegrasyonunu sağlamadaki rolü yadsınamaz derecede önemlidir.

Okullaşma oranları incelendiğinde; 215 bin Suriyelinin kaldığı barınma merkezlerindeki çocukların okullaşma oranı $\% 90$ iken, barınma merkezleri dışında kentlerde yaşayan 3,4 milyon Suriyeli sığınmacı içinde okullaşma oranı yalnızca \% 25'tir (Coşkun ve Emin, 2016: 47).

Aslında eğitime katılma oranları veya kalitesinden daha önemli olan ve üzerinde durmamız gereken konu, bu çocukların bulundukları ortam ve psikolojileridir. Gördükleri ağır zulüm ve iç savaşlar neticesi ülkelerinden göç etmeye mecbur bırakılan, bu yüzden yakınlarını kaybetmiş insanların çocuklarının psikolojilerine ne ölçüde cevap verebildiğimiz önemlidir. Verilen eğitimin kalitesi ne olursa olsun, kaliteli rehberlik olmadan verimli bir eğitimden bahsedilemez.

Göçe tanıklık eden çocuklarda, davranış ve duygusal açıdan bazı problemler görülmektedir. $\mathrm{Bu}$ problemler arasında çoğunlukla daha yüksek anksiyete, depresyon, arkadaş ilişkilerinde problemler, hiperaktivite semptomları, travma sonrası stres bozukluğu, düşük benlik saygısı, düşük yaşam doyumu yer almaktadır (Ekici, 2015: 184).

Mağdur çocukların Türkçeyi henüz öğrenememesinden kaynaklı olarak, duygu ve düşüncelerini anlatamaması, bu durumun çocuktaki psikolojik baskısı ortaya çıkmaktadır.

Türkiye'de geçici koruma altına alınan Suriyeli göçmenlerin gerek eğitim seviyeleri gerekse nitelikleri konusunda yapılan tartışmalar hala canlılığını korumaktadır. Avrupa ülkelerine geçen Suriyeli göçmenlerin nitelik bakımından Türkiye'de bulunanlara kıyasla daha nitelikli oldukları görülmektedir. Gerçekten de, Sadece Almanya'da bulunan Suriyelilerin okuryazar olmayanlarının oranı $\% 5$, Türkiye'deki bu oran resmi olarak $\% 33$, resmi olmayan rakamlarda ise \% 50 civarındadır (Erdoğan, 2016: 35).

Sayıları milyonlarla ifade edilen sığınmacıların büyük çoğunluğu eğitimsiz ve vasıfsızdır. Türkiye tüm bu olumsuzlukların farkında olarak Suriyeli sığınmacı mağdur çocukları ve 
gençleri önemseyerek, koruma altındaki bulunan bu neslin iyi bir eğitim almaları ve meslek sahibi olmaları konusunda politikalar izlenmektedir.

\subsubsection{Sağlık Sorunlarından Doğan Riskler}

Öngörülemeyen sayıdaki Suriyeli sığınmacının Türkiye'ye akın etmesinin beraberinde getirdiği problemlerden birisi de bazı hastalıkların yayılması ile ilgilidir. Bilindiği üzere kızamık, çocuk felci vb hastalıklar bulaşıcıdır. Yetersiz beslenen, temizlik alışkanlığı zayıf, sağlıklı evlerde yaşamayan sı̆̆ınmacılar bulaşıcı hastalıklar için birer kaynak vazifesi görmektedir. Ayrıca barınma merkezleri bulaşıcı hastalıklar için bir zemin oluşturmaktadır (Karasu, 2018: 68-69).

Mersin'de yapılan bir araştırmaya göre, Suriyeli sığınmacıların hijyen koşullarının ve beslenmelerinin yetersiz olması, su ve besinle bulaşan ishal, dizanteri ve hepatit gibi hastalıkların yayılmasına neden olmaktadır (Karaca ve Doğan, 2014: 39). Şanlıurfa'da verem, sarıhumma, dizanteri gibi pek sık görülmeyen vakalarda artış yaşanmaktadır (Urfa Haber, 2016).

Bahsedilen hastalıklarda meydana gelen artışlar nedeniyle, gerek kamplarda gerekse de kamp dışında yerleşik hayatta yaşayan Suriyelilerin, 2013 yılında çıkarılan genelge ile ücretsiz olarak sağlık hizmetleri alabilmektedirler.

\section{SUÇ OLGUSU ve SURIYYLLİ SIĞINMACILARIN BATMAN'DAKİ DURUMU 3.1. KENTLEŞME ve KENT GÜVENLİĞİ}

Kent kavramı en sade tanımlamayla; karmaşık, ayrı cinsten, farklılaşmış toplumsal bütünlüğe sahip, yoğun nüfuslu bir yerleşme olarak söylenebilir (Sencer, 1979: 7). Kent kavramı, merkezi bir yerleşim yerinin ekonomik, siyasal, hukuksal ve toplumsal özelliklerini ifade etmek için kullanılırken, kentleşme, genel olarak yaşanan bu değişim sürecini ifade etmek için kullanılır (Gökçe, 1977: 8).

Görüldüğü üzere kentleşme bir değişim ve gelişim sürecini ifade etmektedir. Bu süreç sadece popülasyonun artmasını değil aynı zamanda bu popülasyonun değişim sürecine olan uyumunu da ifade etmektedir.

Kentleşme süreci, devlet hizmetlerinde artışı da beraberinde getirmektedir. Konumuzla alakalı olarak bireysel ve ulusal anlamda güvenlik boyutunu tesis edecek devlet unsurudur. Can ve mal güvenliği sağlayıcı tedbirler ve önlemler almak, devletin en temel görevleri arasındadır.

Başlangıçta da belirtildiği üzere, Maslow' un piramidindeki önemli basamaklardan biriside güvenlik sekmesidir. Çok eski zamanlardan beri, fiziki ihtiyaçların giderilmesinden sonraki en önemli sekme güvenlik sekmesidir.

Çadırlarda, mağaralarda yaşayan, sürekli ekonomik ve güvenlik gerekçeleri ile göçebe hayatı yaşayan insanlar için bu boyut ayrılmaz bir parçadır. En ilkel zamanlardan beri toplumlar hayatlarını idame ettirebilmek ve insansal ihtiyaçlarını gidermek için güvenlikli bir ortam arzu ederler.

Bahsettiğimiz açıklamalardan hareketle "Kent Güvenliğì", şehirleşme sürecindeki insanların, can ve mal güvenliklerinin sağlanması olarak tanımlanabilir. Bireysel güvenlik, devletlerin esas amaçlarından biri olup, kent güvenliğinin sağlanmasında esas bir yapı taşı niteliğindedir.

Kent güvenliğinin sağlanması hem refah seviyesinin yükselmesine hem hedeflenen demokrasi anlayışının gerçekleşmesine hem de gelişmişliğe önemli katkı ve etkiler sunmaktadır. Güvenli bir ülkede insanlar, insansal ihtiyaçlarına rahatça erişebilmektedir. Kentsel güvenliğin 
sağlanmasıyla, oluşturulan güvenlikli çevre sayesinde insanların yaşam kaliteleri artacak buna bağlı olarak da ekonomik gelişim ortaya çıkacaktır.

\subsection{LINCC KÜLTÜRÜ MAĞDURLARININ "SUÇA KARŞI DURUŞLARI"}

Suç olgusu, sosyolojik açıdan insan potansiyelinin ekonomik ve psikolojik etkilerini barındıran, insanların güvenlik ihtiyaçlarının ortaya çıkmasına neden olan, şehirleşmenin etkisi ile önemi artan, aynı zamanda da toplumda yaşayanlar arasında ortaya çıkan kültür ayrışmasının üreteceği gerginlikten de beslenen bir olgudur.

Göç olgusu sonrası göçmenlerin sosyal yapıya uyumlarında yaşanabilecek sorunlar bu gerginliğe sebep olmaktadır.

Suçun tek bir nedene indirgenemeyecek kadar çok boyutlu bir sosyal olgu olduğunu (Gökulu, 2010: 216), temelinde insan bulunduğundan suç olgusunu ortaya çıkaran etmenlerin çok fazla olduğunu, birkaç teori veya etkenle temellendirilmesi durumunda sağlıksız sonuçlar elde edilebilmektedir.

Leones (2006); yoksulluk, aile değerlerinin kaybolması, kayıtsızlık, adaletsizlik/kötüye Kullanma, zayıf devlet ve yönetim anlayışı, suç korkusu gibi nedenlerle suçun ortaya çıkışını açıklamaya çalışmıştır.

Gerçekten de suç davranışı; sosyal, ekonomik sorunları, psikolojik uyumsuzluk, kontrolsüz şehirleşme, insan popülasyonundaki artış, sağlıssız kentleşme süreçleri, ötekileştirme, önyargılar vb gibi pek çok sorunlu etkenin kapsamında açıklanabilmektedir.

$\mathrm{Bu}$ nedenlere rağmen, göçmenler konusunda ülke vatandaşlarının mensubu oldukları devletin imkân ve hizmetlerine dilediği gibi ulaşamaması, dijital ve sosyal medyada göçmenler aleyhine önyargılar oluşturacak şekilde paylaşımlar yapılması neticesi kamuoyu oluşması, ekonomik, sosyal olumsuzluklar vb nedenlerle popülizm savunulmakta, zaman zaman bozulan/bozulabilecek kamu düzeni göçmenlere dayandırılmak istenmektedir.

Bahsedilen bu etkenlerle Suriyeli sığınmacıların Türkiye'ye kitlesel ve zorunlu göçleri, toplumda bazı önyargılarla suç oranlarının arttığını yaygın olarak dile getirilmektedir. Yapılan saha çalışmalarında; Şanlıurfa'da \%56,3' ü (Karasu, 2016: 1013), Kilis’te \%77,5' i (Memiş, 2015: 109) Suriyeli sığınmacıların suç oranlarını arttırdığını savunmaktadır.

Ötekileştirme ve suç korkusu ile algıların bu yönde olmasının yanında Suriyeli göçmenlerin vasıfsız, eğitimsiz, yoksul olmaları gibi ekonomik açıdan kötü durumda olmaları potansiyel suçlu yani suç işlemeye meyilli olarak görülmelerini sağlamaktadır.

Gerçek rakamlar bu önyargıların yersiz olduklarını göstermektedir. "Ülkelerindeki çatışmalardan kaçarak Türkiye'ye sığınan Suriyelilerin, adli olaylara karışma ve suç oranı 2011 ile 2014 Haziran dönemine kadar on binde otuz üç olmuştur. Suriyeliler, 2013' te Türkiye' de meydana gelen 1 milyon 340 bin 573 olayın, 5 bin 727' sine karışmış, bu rakamlar ile Suriyelilerin, "adli olaylara karışma" oran1 2013 için on binde kırk üç olmuştur. 2013 kayıtlarına göre adli olaya karışan Suriyeli sayısının 5 bin 727 kişi olması, Türkiye'deki 1 milyon 200 bin Suriyeliden on binde kırk yedisinin bu tür olaylara karıştığını ortaya koymaktadır. Suriyeliler, 2011'den itibaren yaşanan toplam 6 milyon 74 bin 369 adli olayın ise 20 bin $48^{\prime}$ ine karışmıştır. Bu süre içinde Suriyelilerin karıştığ 1 olayların oranı on binde 33 olarak gerçekleşmiştir. Suriyelilerin karıştığı olayların yüzde 61' ini belgede sahtecilik, yüzde 21' ini yaralama, yüzde 12' sini hırsılık, yüzde 3' ünü izinsiz çalışma, yüzde 2,4' ünü cinsel olaylar ve yüzde 0,6 ' sı ölümle sonuçlanan olaylar oluşturmaktadır. Suriyeliler, 2014' ün ilk 6 
ayında ise 1 milyon 188 bin 240 olayın, 11 bin 136'sında şüpheli ya da mağdur olarak yer almışlardır" (Anadolu Ajansı, 2014).

İçişleri Bakanlığı’nın 05.07.2017 tarihindeki açıklamalarına baktığımızda, 2014-2017 yılları arasında Suriyelilerin karıştıkları olayların Türkiye'de işlenen toplam asayiş olaylarına oranı \% 1,32 olarak tespit edilmiş, bunların çoğunluğunu da kendi aralarında gerçekleşen adli olaylar olduğu belirtilmiştir (İçişleri Bakanlığı, 2017). 2018 y1lı itibariyle bu oran \%1,46 olarak gerçekleşmiştir (Milliyet Gazetesi, 2018).

Rakamlardan da görüldüğ̈̈ üzere suç işleme potansiyeline sahip olarak görülen Suriyeli sığınmacıların Türkiye'de işlenen asayiş suçları istatistiklerine önemli etkileri olmadığ 1 görülmektedir. Geçici koruma altında bulunan Suriyeliler, Türkiye'de çoğunlukla hırsılılı, kasten yaralama ve öldürme, fuhuş, gasp gibi suçların failleri olarak görülmektedir. Suç verileri bize bu algının önyargılarca oluşturulduğunu göstermektedir.

Türk halkı duyarlı ve hassas bir şekilde ev sahipliği yapmakta, gereksiz ve abartılı şekilde lanse edilmek istenen popülizme prim vermemeli, güvenlik endişelerini ve suç korkusunu hafızalardan silmelidir. Linç kültürüne ve damgalayıcı ifadelere meydan vermemelidir

Mevcut sorunlara rağmen Türk halkı misafirperverliği elden bırakmamış, tedbirler ve önlemler sayesinde Suriyeli sığınmacıların entegrasyon süreci hızlanarak devam etmektedir. Suriyelilerin misafirliği konusundaki statüleri tam olarak netleşmesi halinde toplumsal birliğin daha kolay sağlanabileceği açıktır.

\subsection{BATMAN, SURIYYELİ MISSAFIRLERİ ve KENT GÜVENLIĞİ}

\subsubsection{Batman İli ve Suriyeliler}

Güneydoğu Anadolu Bölgesi'nde yer alan Batman İli'nin güneydoğusunda Bitlis ve Siirt; kuzeyinde Muş; batısında Diyarbakır ve güneyinde Mardin illeri bulunmaktadır. Türkiye'de petrolün bulunduğu ilk bölge olması nedeniyle, gerek ekonomik gerekse de stratejik bir konuma sahiptir. Bu sayede civar illerden daha çabuk gelişme gösteren Batman, 1990 yılında il statüsünü kazanmıştır.

Batman'ın nüfusu 2018 y1lında bir önceki y1la oranla \% 2,37 artarak 599.103 olarak belirlenmiştir. Nüfusun \% 50,31'i erkek, \% 49,69'u kadındır (TÜİK, 2019).

Toplumsal yapıyı oluşturan etnik grupları Kürtler, Yezidiler, Araplar ve Süryanilerin olduğunu söyleyebiliriz. Bu da Batman'ın farklı dillere ve dinlere ev sahipliği yaptığını göstermektedir.

Batman İl Emniyet Müdürlüğü 2019 yılı 10 aylık verilerine göre, Batman'da 22.374 Suriyeli mülteci bulunmaktadır. Suriyelilerin Batman nüfusuna oranı \% 3,73’tür.

Tablo I: 2018-2019 yılı Karşılaştırmalı Türkiye nüfusu, Batman’daki Suriyelilerin Oranları

\begin{tabular}{|c|c|c|c|c|c|c|c|}
\hline & $\begin{array}{c}\text { TÜRKIYE } \\
\text { NÜFUSU }\end{array}$ & $\begin{array}{c}\text { TÜRKIYE'DEKi } \\
\text { SURIYELILER }\end{array}$ & ORANI & BATMAN NÜFUSU & $\begin{array}{c}\text { BATMAN'DAKI } \\
\text { SURIYELiLER }\end{array}$ & $\begin{array}{c}\text { ORANI } \\
\text { BATMAN'DAKI SURIYELILERIN } \\
\text { TÜRKIYE'DEKI SURIYELILERE ORANI }\end{array}$ \\
\hline $\mathbf{2 0 1 8}$ & 80.810 .525 & 3.623 .112 & $4,4 \%$ & 585.252 & 22.846 & $3,9 \%$ & $0,63 \%$ \\
\hline $\mathbf{2 0 1 9}$ & 82.003 .882 & 3.676 .288 & $4,5 \%$ & 599.103 & 22.374 & $3,7 \%$ & $0,61 \%$ \\
\hline
\end{tabular}

Kaynak: Batman İl Emniyet Müdürlüğü 2019 Yılı Verileri 
2018 yılında Türkiye'de bulunan Suriyeliler, bir sonraki y1la oranla 0,1'lik, Batman'daki Suriyeliler ise 0,2 'lik bir artış göstermiştir.

Türkiye'de en fazla Suriye uyruklu sığınmacı bulunduran iller arasında 20. sırada yer alan Batman'da 248 Irak ve 233 Afganistan uyruklu şahıslar da uluslararası koruma kapsamında misafir edilmektedir. Ayrıca 2019 yılı Ekim ayı itibariyle, Batman'da geçici koruma kapsamı altında bulunan Suriye uyruklu şahıslardan 37'si aile ikamet izni, 68'i kısa dönem ikamet izni, 2'si öğrenci ikamet izni olmak üzere toplam 107 kişi ikamet izinli alarak Batman'da ikamet etmektedir.

Batman'da geçici koruma kapsamında kayıt altına alınan Suriyeli şahısların genel olarak Suriye'nin Kamış11, Haseke, Halep, İdlib ve Deyrizor illerinden geldikleri görülmektedir.

Batman'da ikamet eden Suriye uyruklu şahısların ağırlıklı olarak; Şirinevler, Meydan, Çarşı, Aydınlıkevler, 19 Mayıs, Yeni, Yenişehir, Cumhuriyet, Beşevler, Sağlık, Kısmet, Bağlar, Pazaryeri Mahallesi gibi ekonomik anlamda kirası uygun olan bölgelerde ikamet ettikleri ve geçimlerini daha çok tekstil, sanayi, gündelik ve mevsimlik işlerde çalışarak sağladıkları görülmektedir.

\subsubsection{Batman'da Bulunan Suriyelilerin Suç ile İlişkisi (2018-2019 Yılları Mukayesesi)}

Suç türleri boyutuna, taraflarına, maddi ve manevi unsurlarına göre 4 ana başlık altına toplanmıştır. Bunlar; "Kişilere Karşı”, "Malvarlığına Karşı”, "Millete ve Devlete Karşı", “Topluma Karşı" ve "Takibi Gereken” olarak sınıflandırılmıştır.

Kişilere karşı işlenen suçlar; insanın fiziki bütünlüğüne karşı yapılan her türlü saldırıları, malvarlığına karşı işlenen suçlar; mali değeri olan her türlü konuların sahibi olan zilyetlere karşı işlenen suçları, millete ve devlete karşı işlenen suçlar; devletin egemenliğine, kurumlarına, görevlilerine karşı işlenen, kamuyu ilgilendiren her türlü suçları, takibi gereken suçlar; illegal toplantı gösteri yürüyüşleri, ateşli silahlar ile ilgili suçları, kültür ve tabiat varlıklarına karşı işlenen suçlar vb konuları, topluma karşı işlenen suçlar; aile hukukuna karşı, bilişim sistemleri ve resmi belgelerle ilgili suçları, genel güvenliğe yönelik vb topluma zarar veren suçları kapsamaktadır.

\subsubsection{Suriyeli Şahısların 2018 Yılı Suç Analizi}

Batman İl Emniyet Müdürlüğü'nün 2018 yılına ait suç istatistikleri incelendiğinde, yapılan adli işlemlerde "şüpheli", "müşteki" ve "bilgi sahibi" olarak 219 yabancı uyruklu şahıs bulunmakta, bunlardan 202'sinin Suriyeli olduğunu görmekteyiz.

Tablo II: 2018 yılı Batman İli’ nde gerçekleşen suç türlerine göre dağılımı ve Suriyelilerin bu suçlara karışma oranları

\begin{tabular}{|c|c|c|c|c|c|c|c|c|c|}
\hline \multicolumn{10}{|c|}{2018 YILI (12 AY) } \\
\hline \multirow{2}{*}{ SUÇ TÜRLERI } & \multirow{2}{*}{ OLAY SAYISI } & \multirow{2}{*}{ ŞÜPHELI } & \multirow{2}{*}{ MÜŞTEKi } & \multicolumn{6}{|c|}{ SURIYELI ŞAHISLARIN KARIŞTIKLARI } \\
\hline & & & & OLAY SAYISI & ORANI & ŞÜPHELI & ORANI & MÜŞTEKi & ORANI \\
\hline KişiLiLERE KARŞI & 3736 & 2987 & 4612 & 97 & $2,6 \%$ & 42 & $1,4 \%$ & 74 & $1,6 \%$ \\
\hline MALVARLIĞINA KARŞI & 3343 & 2042 & 2880 & 59 & $1,8 \%$ & 32 & $1,6 \%$ & 32 & $1,1 \%$ \\
\hline MILLETE VE DEVLETE KARŞI & 214 & 209 & 107 & 3 & $1,4 \%$ & 3 & $1,4 \%$ & 0 & $0,0 \%$ \\
\hline TAKIBI GEREKEN & 1999 & 632 & 1443 & 35 & $1,8 \%$ & 3 & $0,5 \%$ & 31 & $2,1 \%$ \\
\hline TOPLUMA KARŞI & 810 & 774 & 263 & 22 & $2,7 \%$ & 19 & $2,5 \%$ & 3 & $1,1 \%$ \\
\hline TOPLAM & 10102 & 6644 & 9305 & 216 & $2,1 \%$ & 99 & $1,5 \%$ & 140 & $1,5 \%$ \\
\hline
\end{tabular}

Kaynak: Batman İl Emniyet Müdürlüğü 2018 Yılı Suç Verileri 
Tablo II' de görüldüğü üzere, Batman İli' nde 2018 y1lı içerisinde 10.102 olay meydana gelmiştir. Kişilere karşı 3.736 olay, malvarlığına karşı 3343, millete ve devlete karşı 214, takibi gereken 1.999 ve topluma karş1 810 olay gerçekleşmiştir.

Kişilere karşı işlenen suçlar türünde toplamda 3.736 olay ile ilgili 2.987 şüpheli şahıs bulunmaktadır. Bu kategoride bulunan suçların \% 2,6'lık bir orana karşılık gelen 97 olayda Suriyeli şahısların bulunduğunu, bunlardan sadece \% 1,4'üne karşılık gelen 42 Suriyeli şahsın şüpheli sıfatıyla haklarında adli işlem yapıldığını görmekteyiz.

Malvarlığına karşı işlenen suçlar türünde toplamda 3.343 olay ile ilgili 2.042 şüpheli şahıs bulunmaktadır. Bu kategoride bulunan suçların \% 1,8'lik bir orana karşılık gelen 59 olayda Suriyeli şahısların bulunduğunu, bunlardan sadece \% 1,6'ine karşılık gelen 32 Suriyeli şahsın şüpheli sıfatıyla haklarında adli işlem yapıldığını görmekteyiz.

Millete ve Devlete karşı işlenen suçlar türünde toplamda 214 olay ile ilgili 209 şüpheli şahıs bulunmaktadır. Bu kategoride bulunan suçların \% 1,4'lük bir orana karşıllk gelen sadece 3 olayda Suriyeli şahsın bulunduğunu, sadece \% 1,4'üne karşılık gelen 3 Suriyeli şahsın şüpheli sıfatıyla hakkında adli işlem yapıldığını görmekteyiz.

Takibi gereken suçlar türünde toplamda 1.999 olay ile ilgili 632 şüpheli şahıs bulunmaktadır. Bu kategoride bulunan suçların \% 1,8'lik bir orana karşılık gelen 35 olayda Suriyeli şahısların bulunduğunu, bunlardan sadece \% 0,5'ine karş1lık gelen 3 Suriyeli şahsın şüpheli sifatıyla haklarında adli işlem yapıldığını görmekteyiz.

Topluma karşı işlenen suçlar türünde toplamda 810 olay ile ilgili 774 şüpheli şahıs bulunmaktadır. Bu kategoride bulunan suçların \% 2,7'lik bir orana karşılık gelen 22 olayda Suriyeli şahısların bulunduğunu, bunlardan sadece \% 2,5'ine karşılık gelen 19 Suriyeli şahsın şüpheli sıfatıyla haklarında adli işlem yapıldığını görmekteyiz.

Batman İli' nde 2018 yılında sınıflandırılan 5 adet suç türünde toplam 10.102 olay gerçekleşmiş ve bu olaylarla ilgili 6.644 şüpheli hakkında adli işlemler yapılmıştır. İşlenen suçların yalnızca \% 2,1'ine karş1lık gelen 216 olayda Suriyeli şahıslar bulunmakta, bunlardan \% 1,5'e karşılık gelen 99 şüphelinin Suriyeli olduğunu görmekteyiz.

\subsubsection{Suriyeli Şahısların 2019 Yılı (10 Aylık) Suç Analizi}

Batman İl Emniyet Müdürlüğü’nün 2019 yılına ait (10 Aylık) suç istatistikleri incelendiğinde, yapılan adli işlemlerde "şüpheli", "müşteki" ve "bilgi sahibi" olarak 42 yabancı uyruklu şahıs bulunmakta, bunlardan 31 'sinin Suriyeli olduğunu görmekteyiz.

Tablo III: 2019 yılı (10 Aylık) Batman İli’ nde gerçekleşen suç türlerine göre dağılımı ve Suriyelilerin bu suçlara karışma oranları

\begin{tabular}{|c|c|c|c|c|c|c|c|c|c|}
\hline \multicolumn{10}{|c|}{2019 YILI (10 AY) } \\
\hline \multirow{2}{*}{ SUÇ TÜRLERI } & \multirow{2}{*}{ OLAY SAYISI } & \multirow{2}{*}{ ŞÜPHELi } & \multirow{2}{*}{ MÜŞTEKi } & \multicolumn{6}{|c|}{ SURIYELI ŞAHISLARIN KARIŞTIKLARI } \\
\hline & & & & OLAY SAYISI & ORANI & ŞÜPHELi & ORANI & MÜŞTEKi & ORANI \\
\hline KIŞiLERE KARŞI & 3101 & 2548 & 3738 & 102 & $3,3 \%$ & 85 & $3,3 \%$ & 102 & $2,7 \%$ \\
\hline MALVARLIĞINA KARŞI & 2776 & 1517 & 2661 & 54 & $1,9 \%$ & 34 & $2,2 \%$ & 54 & $2,0 \%$ \\
\hline MiLLETE VE DEVLETE KARŞI & 168 & 158 & 90 & 7 & $4,2 \%$ & 7 & $4,4 \%$ & 4 & $4,4 \%$ \\
\hline TAKIBi GEREKEN & 1508 & 456 & 1097 & 27 & $1,8 \%$ & 3 & $0,7 \%$ & 24 & $2,2 \%$ \\
\hline TOPLUMA KARŞI & 744 & 743 & 213 & 27 & $3,6 \%$ & 26 & $3,5 \%$ & 8 & $3,8 \%$ \\
\hline TOPLAM & 8297 & 5422 & 7799 & 217 & $2,6 \%$ & 155 & $2,9 \%$ & 192 & $2,5 \%$ \\
\hline
\end{tabular}

Kaynak: Batman İl Emniyet Müdürlüğü 2019 Yılı Suç Verileri 
Tablo III' de görüldüğü üzere, Batman İli' nde 2019 y1lı (10 Aylık) içerisinde 8.297 olay meydana gelmiştir. Kişilere karş1 3.101 olay, malvarlığına karş1 2776, millete ve devlete karş1 168, takibi gereken 1.508 ve topluma karş1 744 olay gerçekleşmiştir.

Kişilere karş1 işlenen suçlar türünde toplamda 3.101 olay ile ilgili 2.548 şüpheli şahıs bulunmaktadır. Bu kategoride bulunan suçların \% 3,3'lük bir orana karşılık gelen 102 olayda Suriyeli şahısların bulunduğunu, bunlardan sadece \% 3,3'üne karşılık gelen 85 Suriyeli şahsın şüpheli sıfatıyla haklarında adli işlem yapıldığını görmekteyiz.

Malvarlığına karşı işlenen suçlar türünde toplamda 2.776 olay ile ilgili 1.517 şüpheli şahıs bulunmaktadır. Bu kategoride bulunan suçların \% 1,9'luk bir orana karşılık gelen 54 olayda Suriyeli şahısların bulunduğunu, bunlardan sadece \% 2,2'sine karşılık gelen 34 Suriyeli şahsın şüpheli sıfatıyla haklarında adli işlem yapıldığını görmekteyiz.

Millete ve Devlete karşı işlenen suçlar türünde toplamda 168 olay ile ilgili 158 şüpheli şahıs bulunmaktadır. Bu kategoride bulunan suçların \% 4,2'lik bir orana karşıllk gelen sadece 7 olayda Suriyeli şahsın bulunduğunu, sadece \% 4,4'üne karşılık gelen 7 Suriyeli şahsın şüpheli sıfatıyla hakkında adli işlem yapıldığını görmekteyiz.

Takibi gereken suçlar türünde toplamda 1.508 olay ile ilgili 456 şüpheli şahıs bulunmaktadır. Bu kategoride bulunan suçların \% 1,8'lik bir orana karşılık gelen 27 olayda Suriyeli şahısların bulunduğunu, bunlardan sadece \% 0,7'sine karşılık gelen 3 Suriyeli şahsın şüpheli sifatıyla haklarında adli işlem yapıldığını görmekteyiz.

Topluma karşı işlenen suçlar türünde toplamda 744 olay ile ilgili 743 şüpheli şahıs bulunmaktadır. Bu kategoride bulunan suçların \% 3,6'lık bir orana karşılık gelen 27 olayda Suriyeli şahısların bulunduğunu, bunlardan sadece \% 3,5'ine karşılık gelen 26 Suriyeli şahsın şüpheli sıfatıyla haklarında adli işlem yapıldığını görmekteyiz.

Batman İli' nde 2019 yılında (10 Aylık) sınıflandırılan 5 adet suç türünde toplam 8.297 olay gerçekleşmiş ve bu olaylarla ilgili 5.422 şüpheli hakkında adli işlemler yapılmıştır. İşlenen suçların yalnızca \% 2,6'sına karşılık gelen 217 olayda Suriyeli şahıslar bulunmakta, bunlardan \% 2,9'una karş1lık gelen 155 şüphelinin Suriyeli olduğunu görmekteyiz.

\subsubsection{Suriyeli Şahısların 2018 Yılı (10 Aylık) Suç Analizi}

2018-2019 yıllarında Suriyelilerin Batman'daki suç olgusu karşısındaki duruşlarını tam olarak karşılaştırabilmemiz için 2018 yılına ait 10 aylık verilerle 2019 y1lına ait 10 aylık verileri kıyaslamamız gerekmektedir.

Batman İl Emniyet Müdürlüğü’nün 2018 yılına ait (10 Aylık) suç istatistikleri incelendiğinde, yapılan adli işlemlerde "şüpheli", "müşteki" ve "bilgi sahibi" olarak 228 yabanc1 uyruklu şahıs bulunmakta, bunlardan 204'ünün Suriyeli olduğunu görmekteyiz. 
Tablo IV: 2018 yılı (10 Aylık) Batman İli’ nde gerçekleşen suç türlerine göre dağılımı ve Suriyelilerin bu suçlara karışma oranları

\begin{tabular}{|c|c|c|c|c|c|c|c|c|c|}
\hline \multirow{3}{*}{ SUÇ TÜRLERI } & \multicolumn{9}{|c|}{2018 YILI (10 AY) } \\
\hline & \multirow{2}{*}{ OLAY SAYISI } & \multirow{2}{*}{ ŞÜPHELi } & \multirow{2}{*}{ MÜŞTEKi } & \multicolumn{6}{|c|}{ SURIYELI KARIŞAN SAYILARI } \\
\hline & & & & OLAY SAYISI & ORANI & ŞÜPHELI & ORANI & MÜŞTEKi & ORANI \\
\hline KIŞiLERE KARŞI & 3211 & 2561 & 3968 & 83 & $2,6 \%$ & 36 & $1,4 \%$ & 62 & $1,6 \%$ \\
\hline MALVARLIĞINA KARŞI & 2798 & 1769 & 2346 & 51 & $1,8 \%$ & 25 & $1,4 \%$ & 29 & $1,2 \%$ \\
\hline MILLETE VE DEVLETE KARŞI & 171 & 168 & 87 & 2 & $1,2 \%$ & 3 & $1,8 \%$ & 0 & $0,0 \%$ \\
\hline TAKIBi GEREKEN & 1692 & 534 & 1224 & 32 & $1,9 \%$ & 3 & $0,6 \%$ & 28 & $2,3 \%$ \\
\hline TOPLUMA KARŞI & 658 & 629 & 219 & 18 & $2,7 \%$ & 17 & $2,7 \%$ & 1 & $0,5 \%$ \\
\hline TOPLAM & 8530 & 5661 & 7844 & 186 & $2,2 \%$ & 84 & $1,5 \%$ & 120 & $1,5 \%$ \\
\hline
\end{tabular}

\section{Kaynak: Batman İl Emniyet Müdürlüğü 2018 Yılı Suç Verileri}

Tablo IV' de görüldüğü üzere, Batman İli' nde 2018 y1lı (10 Aylı) içerisinde 8.530 olay meydana gelmiştir. Kişilere karş1 3.211 olay, malvarlığına karş1 2798, millete ve devlete karş1 171, takibi gereken 1.692 ve topluma karş1 658 olay gerçekleşmiştir.

Kişilere karşı işlenen suçlar türünde toplamda 3.211 olay ile ilgili 2.561 şüpheli şahıs bulunmaktadır. Bu kategoride bulunan suçların \% 2,6' lık bir orana karşılık gelen 83 olayda Suriyeli şahısların bulunduğunu, bunlardan sadece \% 1,4'üne karşılık gelen 36 Suriyeli şahsın şüpheli sıfatıyla haklarında adli işlem yapıldığını görmekteyiz.

Malvarlığına karşı işlenen suçlar türünde toplamda 2.798 olay ile ilgili 1.769 şüpheli şahıs bulunmaktadır. Bu kategoride bulunan suçların \% 1,8'lik bir orana karşılık gelen 51 olayda Suriyeli şahısların bulunduğunu, bunlardan sadece \% 1,4'üne karşılık gelen 25 Suriyeli şahsın şüpheli sıfatıyla haklarında adli işlem yapıldığını görmekteyiz.

Millete ve Devlete karşı işlenen suçlar türünde toplamda 171 olay ile ilgili 168 şüpheli şahıs bulunmaktadır. Bu kategoride bulunan suçların \% 1,2'lik bir orana karşıllk gelen sadece 2 olayda Suriyeli şahsın bulunduğunu, sadece \% 1,8'ine karşılık gelen 3 Suriyeli şahsın şüpheli sıfatıyla hakkında adli işlem yapıldığını görmekteyiz.

Takibi gereken suçlar türünde toplamda 1.692 olay ile ilgili 534 şüpheli şahıs bulunmaktadır. Bu kategoride bulunan suçların \% 1,9'luk bir orana karşılık gelen 32 olayda Suriyeli şahısların bulunduğunu, bunlardan sadece \% 0,6'sına karşılık gelen 3 Suriyeli şahsın şüpheli sıfatıyla haklarında adli işlem yapıldığını görmekteyiz.

Topluma karşı işlenen suçlar türünde toplamda 658 olay ile ilgili 629 şüpheli şahıs bulunmaktadır. Bu kategoride bulunan suçların \% 2,7’lik bir orana karşılık gelen 18 olayda Suriyeli şahısların bulunduğunu, bunlardan sadece \% 2,7'sine karşılık gelen 17 Suriyeli şahsın şüpheli sıfatıyla haklarında adli işlem yapıldığını görmekteyiz.

Batman İli’ nde 2018 yılında (10 Aylık) sınıflandırılan 5 adet suç türünde toplam 8.530 olay gerçekleşmiş ve bu olaylarla ilgili 5.661 şüpheli hakkında adli işlemler yapılmıştır. İşlenen suçların yalnızca \% 2,2'sine karşılık gelen 186 olayda Suriyeli şahıslar bulunmakta, bunlardan \% 1,5'ine karşılık gelen 84 şüphelinin Suriyeli olduğunu görmekteyiz.

\subsubsection{Suriyeli Şahısların 2018 Yılı (10 Aylık) - 2019 Yılı (10 Aylık) Karşılaştırmalı Suç Analizi}

Suriyeli şahısların 2018 yılı (10 Aylık) - 2019 Yılı (10 Aylık) karşılaştırmalı suç analizine baktığımızda ise sonuç şu şekilde olmaktadır; 
Tablo V: 2018 yılı (10 Aylık) - 2019 yılı (10 Aylık) Batman İli’ nde gerçekleşen suç türlerine göre dağılımı ve Suriyelilerin bu suçlara karışma oranları

\begin{tabular}{|c|c|c|c|c|c|c|}
\hline \multicolumn{2}{|c|}{ 2018-19 (10) AYLIK KARŞILAŞTIRMALI ARTIŞ\&AZALIŞ ORANLARI } \\
\hline \multirow{2}{*}{ SUÇ TÜRLERI } & \multirow{2}{*}{ OLAY SAYISI } & \multirow{2}{*}{ şÜPHELI } & \multirow{2}{*}{ MÜŞTEKi } & \multicolumn{3}{|c|}{ SURIYELi KARIŞAN ORANI } \\
\cline { 5 - 7 } & & & & OLAY SAYISI & ŞÜPHELI & MÜŞTEKi \\
\hline KişiLERE KARŞI & $-3,4 \%$ & $-0,5 \%$ & $-5,8 \%$ & $22,9 \%$ & $136,1 \%$ & $64,5 \%$ \\
\hline MALVARLIĞINA KARŞI & $-0,8 \%$ & $-14,2 \%$ & $13,4 \%$ & $5,9 \%$ & $36,0 \%$ & $86,2 \%$ \\
\hline MiLLETE VE DEVLETE KARŞI & $-1,8 \%$ & $-6,0 \%$ & $3,4 \%$ & $250,0 \%$ & $133,3 \%$ & $\ldots .$. \\
\hline TAKiBi GEREKEN & $-10,9 \%$ & $-14,6 \%$ & $-10,4 \%$ & $-15,6 \%$ & $0,0 \%$ & $-14,3 \%$ \\
\hline TOPLUMA KARŞI & $13,1 \%$ & $18,1 \%$ & $-2,7 \%$ & $50,0 \%$ & $52,9 \%$ & $700,0 \%$ \\
\hline
\end{tabular}

\section{Kaynak: Batman İl Emniyet Müdürlüğü 2018-2019 Yılı 10 Aylık Suç Verileri}

Tablo V' e göre, 2018 yılı (10 Aylık) ile 2019 yılı (10 Aylık) karşılaştırılmasında; Batman'daki suç sayılarının toplamda \% 13,1, şüpheli sayısının \% 18,1 arttığını söyleyebiliriz. Batman'da bulunan Suriyelilerin karıştıkları olay sayılarında \% 50, şüpheli sıfatıyla haklarında adli işlem yapılan Suriyelilerin \% 53,9 oranında arttığını görmekteyiz.

\subsection{VERILLERIN ANALIZİ ve DEĞERLENDİRM}

Batman İl geneline ait, gerek 2018 yll 12 aylık, gerek 2018 yılı 10 aylık ve gerekse de 2019 yılı 10 aylık suç verileri incelendiğinde; tüm bu veriler 1şığında, Batman'da meydana gelen suçlarda burada yaşayan Suriyelilerin rolü yok denecek kadar azdır. Suç istatistik tablolarında görüldüğü üzere, 2018 ve 2019 yılları temel alındığında, Suriyelilerin Batman'da işlenen suçlar üzerindeki etkisi \% 2,6'nın altındadır. Adli olayların şüphelisi olarak haklarında işlem yapılan Suriyelilerin \% 2,9 altında olduğu düşünüldüğünde, Suriyelilerin adli olaylardaki etkisinin ne denli düşük olduğunu görmekteyiz.

Batman'da yaşayan Suriyelilerin suça karışma durumları, çalışmada bahsedildiği gibi Türkiye'deki Suriyelilerin suça karışma durumlarına paralellik göstermektedir. Geçici koruma altında bulunan Suriyelilerin, Türkiye'de meydana gelen adli olaylara hiçbir şekilde ciddi bir katkısı bulunmamaktadır.

\section{SONUÇ}

Arap Baharının kelebek etkisi yaratarak tüm Ortadoğu coğrafyasında etkili olmaya başlamasının ardından, Suriye'de ortaya çıkan iç savaş sonucunda, 2010 yılında yaklaşık 21,5 milyon nüfuslu Suriye'de 250 bine yakını hayatını kaybetmiş, nüfusun yarısından fazlası evlerini, 6 milyona yakını da ülkelerini terk etmek zorunda bırakılmıştır.

“Kavimler Göçü” olarak adlandırabileceğimiz bu göçmen akımına Türkiye sessiz kalmayarak “açık kapı politikası" ilan ederek, Nisan 2011'den bu yana kapılarını mağdur Suriyelilere açmış, tüm insani yardımları ve imkânları seferber etmiş, yapılan hukuksal düzenleme ile sayıları 3,6 milyonun üzerinde Suriyeliye, geçici koruma statüsü kazandırmıştır.

Türkiye, geçici koruma altında bulunan Suriyelileri, değer olarak görmekte, ev sahipliği rolüyle insan haklarına verdiği önemle sayılarına bakmaksızın tüm mağdur Suriyelilere imkânlarını seferber etmiştir.

Ancak misafirlik sürecinin uzun olması ve bu sürecin ne zaman biteceğinin belli olmaması Türkiye'de birtakım sosyal, siyasal ve ekonomik boyuta olan uyum sorunlarını ortaya çıkarmakta ve hatta insanların güvenlik algılarını bile sirayet etmektedir. Bugüne kadar geçici koruma altında bulunan Suriyeli sığınmacılar ile ev sahibi ülke vatandaşları arasında toplumsal huzuru sarsacak hiçbir sansasyonel olay yaşanmamıştır. 
Ayrıca Türkiye'nin en uzun kara sınırına sahip komşusu Suriye'de yaşanan iç savaş ve şiddet olayları, bölgenin istikrarsızlığa kavuşmasına ayrıca terör örgütlerinin daha kolay yuvalanmasına neden olmaktadır. Söz konusu terörist faaliyetlerini engellemek, meydana gelebilecek sınır ihlalleri ve insan kaçakçılığı gibi suçlarla mücadelede daha çok enerji harcamaktadir.

Tüm bu bilgiler ışığında, Türkiye insan odaklı davranış biçimini kabul ederek, popülizm söylemlerine karşı durmuş, ötekileştirmeyi her daim reddetmiş ve bunu politikasına da yansitmıştır.

Buradan hareketle, Batman'da meydana gelen suçların Suriyelilerden kaynaklandığını, Suriyelilerin hukuk tanımayan suça meyilli profillerinin olduğunu, ekonomik problemli Suriyelilerin suç işlemeyi hayat tarzı olarak benimsedikleri gibi Suriyelileri günah keçisi ilan edici iddiaların ortaya çıkması durumunda; bu asılsız iddiaların daha önce kulaktan duyma bilgilerle veya sosyal medya, dijital basın yoluyla oluşturulan önyargılar sonucu olarak ortaya atılmış olduğunu söyleyebiliriz.

Çalışmada da bahsedildiği üzere gerek ekonomiyle gerekse de güvenlik boyutuyla ilgili ortaya çıkabilecek gerçek dışı olumsuz kanaatlerin basın veya sosyal medya üzerinden yayılması hem Türkiye'yi hem de Suriyeli sığınmacıları zorda bırakmaktadır. Bu türden linç kültürüne hizmet eden her türlü olumsuz söylemler, toplumda önyargıların ve ötekileştirmenin oluşmasına neden olacaktır.

Çalışmamızla ilgili olarak; Suriyeli sığınmacıların Türkiye'de ve yerelde Batman ilinde asayiş suçlarına karışma istatistikleri incelendiğinde, toplumda zaman zaman güvenlik boyutu ile ilgili oluşan önyargıların gerçek dışı ve yersiz olduklarını görmekteyiz.

Aynı şekilde ekonomi konusunda da ortaya atılan işsizlik, ücretlerin düşmesi vb şekildeki önyargıların da, yine gerçek dışı olduğunu söyleyebiliriz.

Toplumda bazı önyargılarla oluşturulmak istenen linç kültürü, sadece Suriyeli sığınmacılara değil aynı zamanda Türkiye'de bulunan tüm yabancı misafirlerin ve burayı yurt kabul edip yerleşen azınlıkların sosyal yaşamlarını ve güvenliklerini de olumsuz etkilemektedir.

Türkiye'de ve dünyada, sığınmacıların yerleşmesinden önce de suç olgusu mevcuttu. Evrensel olarak algılanan suç olgusunun neden olduğu etkenlerin tümüne bakmak yararlı olacaktır. Sadece tek veya birkaç unsura bakarak suç olgusunu sığınmacı insanlara mal etmek son derece yanlıştır.

Temelinde insan faktörü olan ve bu nedenle komplike bir yapıya sahip olan suç olgusunu irdelerken, sadece niteliksiz ve vasıfsız olarak göçmenlere bunu dayandırmak, onları potansiyel suçlu olarak görmek yanlış ve tehlikeli bir yaklaşımdır. Göç ve suç ilişkisinde, parçaların tümüne bakılmalı, tüme varım metodu uygulanarak çıkarımlarda bulunulmalıdır.

Türkiye'de gerçekleşen adli olayların istatistikleri ile Batman İlinde meydana gelen adli olayların istatistiklerinin birbirlerine paralel olduğunu söyleyebiliriz. Bazı önyargılarla sosyal, ekonomik ve siyasi sorun olarak görülen Suriyelilerin, aslında ortaya atılan sorunların sebebi olmadıkları, temelsiz yayılan bilgi kirliliğinin masum şüphelileri olduklarını söylemek mümkündür.

Türkiye’ye zorunlu göç ederek geçici koruma statüsü altına alınan Suriyeli sığınmacıların;

-Misafirlik süresi ivedilikle belirlenerek, bu konudaki belirsizliğin psikolojik baskıya dönüşmesinin önüne geçilmesi, 
- Başta okul çağındaki çocukların "kayıp nesil” olarak adlandırılmaması için eğitimlerinin daha kapsayıcı olarak yerine getirilmesi,

-Sosyal yaşama entegrasyonlarının hızlandırılması için dil sorunu çözülmeli, dil öğretimi alanında kursların arttırılması,

-Üretici hale getirip ekonomik bağımsızlıklarını kazandırmak ve toplumdaki ekonomik alandaki kaygıları azaltmak için meslek edindirme çalışmalarının arttırılması ve kamusal alanda daha çok yer almalarının sağlanması,

-Toplumun değer taşlarından olan STK'ların sığınmacılar konusunda daha fazla rol oynamalar1,

- Toplumu bir arada tutan bütünleyici politikaların izlenmesi,

-Nefret dilinin ve linç kültürünün terk edilerek, kutuplaştırıcı popülizmin etkisi terkedilmesi,

- Kamplarda veya kamp dışında yaşayan mültecilerin insani koşulları arttırıcı mekanizmaların oluşturulması,

-Göçün mağdurları olan başta çocuklar olmak üzere tüm yetişkinlerde, meydana gelebilecek sosyo-psikolojik travmaları atlatabilmeleri için kamu kurumlarınca gerekli rehabilite hizmetlerini sunması gibi hususların gereği açıktır. 


Y Year:4, Volume:4, Number:8 / Yul:4, Cilt:4, Sayl:8 / 2020

\section{KAYNAKCAA}

Afet ve Acil Durum Yönetimi Başkanlığı Yayınları (2013), Türkiye'deki Suriyeli Sı̆̆ınmacılar 2013 Saha Araştırması Sonuçları, Ankara: AFAD Yayını.

Afet ve Acil Durum Yönetimi Başkanlığ 1 (2015), Suriye Afet Raporu. 20 Kasım 2019 tarihinde https://www.afad.gov.tr/TR/IcerikDetay1.aspx?ID=16\&IcerikID=747 adresinden edinilmiştir.

Afet ve Acil Durum Yönetimi Başkanlığı (2018), https://www.afad.gov.tr, erişim tarihi: 01.10.2019

Ağır, O. ve Sezik, M. (2015), Suriye'den Türkiye'ye Yaşanan Göç Dalgasından Kaynaklanan Güvenlik Sorunları, Birey ve Toplum Sosyal Bilimler Dergisi, 5(9), ss.95-122.

Anadolu Ajansı (2014). Suriyelilerin Adli Olaylara Karışma Oranı On Binde 33. 19 Kasım 2019 tarihinde http://www.aa.com.tr/tr/tag/391660--suriyelilerin-adli-olaylara-karisma-orani-onbinde-33 adresinden edinilmiştir.

Anderson, B. (2015), Hayali Cemaatler Milliyetçiliğin Kökenleri ve Yayılması. (İ. Savaşır, Çev.) İstanbul: Metis Yayınları.

Arıcan E. (2019), Gündelik Hayat Bağlamında Suriyeli Sığınmacıları Şeytanlaştırma Pratikleri: Önder Mahallesi Örneği, Hacettepe Üniversitesi Sosyal Bilimler Enstitüsü İletişim Bilimleri Anabilim Dalı Kültürel Çalışmalar ve Medya Bilim Dalı.

Aşkar İ. (2017), Suriye İç Savaşı'nın AB'ye Yansımaları: Mülteci Sorunu ve Uluslararası Terörizm, Türkiye-AB Illişkilerinde Yeni Bir Konu: Mülteci Sorunu ve Türkiye-AB İşbirliği, Editörler: Yaprak Gülcan, Sedef Akgüngör, Yeşim Kuştepeli, İktisadi Kalkınma Vakfı Yayınları, Yayın No: 293.

Aydın, S., Oğuz, H. Ş. (2015), Şeytanlaştırılan Gruplar: Ulus Devlet Pratiğinde Ötekileştirmenin ve Etnik Kurtulmanın Mültecilik Bağlamında Zihinsel İnşası. E. Parlak içinde, Ötekinin Var Olma Sancısı Türk Politik Kültüründe Şeytanlaştırma Ĕgilimleri, Bursa Dora Yayınc1lik, s. 301-348.

Bahçekapıl1, C. ve Çetin, B. (2015), The Impacts of Forced Migration on Regional Economies: The Case of Syrian Refugees in Turkey. International Business Research, 8 (9), s.1-15.

Başak, C. (2011), Mülteciler, Sı̆̆ınmacılar ve Yasa Dışı Göçmenler, Ankara: TC İçişleri Bakanlığı Yayını, Yayın No:686.

Batman İl Emniyet Müdürlüğü (2018), Batman İli Suç İstatistikleri ve Suriyeli Sığınmacıların Suça Karışma Verileri.

Batman İl Emniyet Müdürlüğü (2019), Batman İli Suç İstatistikleri ve Suriyeli Sığınmacıların Suça Karışma Verileri.

Binark, M. ve Bayraktutan, G. (2013), Ayın Karanlık Yüzü Yeni Medya ve Etik. İstanbul: Kalkedon Yayınları.

Boulden, J. (2009), Terrorism and Civil Wars. Civil Wars, 11(1), s, 5-21.

Coşkun, İ. ve M. Emin (2016), Türkiye'deki Suriyelilerin Eğitimde Yol Haritası: Fırsatlar ve Zorluklar, İstanbul: SETA Yayınları.

Çambay S. (2019), Türkiye'deki Suriyeli Mültecilerin Dijital Gazetelerdeki Temsil Sorunu, Turkish Studies, Volume 14, Issue 1. 
Demir, O.Ö. (2015), Göç Politikaları, Toplumsal Kaygılar ve Suriyeli Mülteciler, Ankara, Global Politika ve Strateji Yayını.

Demirel C. A. (2013), Türkiye'ye Göç Eden Suriyelilere İlişkin Haberler ve Kamuoyuna Olası Etkileri, II. Türkiye Lisanüstü Çalışmaları Kongresi - Bildiriler Kitabı II, Editör Ümit Güneş. Bursa, Star Ajans Matbaacılık.

Dinçer, S., Karaca, S., Yavuz, H. (2013), Göçün ikinci yılında Suriyeli savaş mağdurları. Analist. 09 Eylül 2019 tarihinde http://www.usakanalist.com/detail.php?id=540 adresinden edinilmiştir.

Doğanay, Ü., Keneş H. (2016), Yazılı Basında Suriyeli 'Mülteciler': Ayrımcı Söylemlerin Rasyonel ve Duygusal Gerekçelerinin İnşası, Mülkiye Dergisi, 40(1), s.143-184.

Euro-Mediterranean Human Rights (2011), Belirsizlik: Türkiye'deki Suriyeli Mültecilerin Durumunu En İyi Anlatan Kelime. 10 Kasım 2019 tarihinde https://www.refworld.org/cgiin/texis/vtx/rwmain/opendocpdf.pdf?docid=51501102107 4\&reldoc=y adresinden edinilmiştir.

Erdoğan, M. (2014), Türkiye'deki Suriyeliler: Toplumsal Kabul ve Uyum Araştırması, Ankara, Hacettepe Üniversitesi Göç ve Siyaset Araştırmaları Merkezi.

Erdoğan M. (2016), Nitelik Sorunu ve Suriyeli Mültecilerin Entegrasyonuna İlişkin Gelecek Projeksiyonları, Mülteci Krizi Ekseninde Türkiye-Ab İşbirliği, İktisadi Kalkınma Vakfı Yayınlar1, Yayın No: 289.

Eren, S. (2017), Güç kazanan sağc1 popülist söylemlerin nedenleri ve etkileri: Fransa ve Hollanda örneği, IKV Değerlendirme Notu, say1: 198.

Ekici, F.Y. (2015), Çocukların Göçle Birlikte Yaşadıkları Eğitim Sorunları Üzerine Bir İnceleme, A. Esen (ed.) Disiplinler arası Göç Sempozyumu, İstanbul: Sabahattin Zaim Üniversitesi, s.179-201.

European Civil Protection and Humanitarian Aid Operations (2016), ECHO Factsheet. 10 Kasim 2019 tarihinde http://ec.europa.eu/echo/files/aid/countries/factsheets /syria_en.pdf,1-3 adresinden edinilmiştir.

Göç İdaresi Genel Müdürlüğü (2015), https://www.goc.gov.tr, Ekim 2015.erişim tarihi: 25 Kasim 2019.

Göç İdaresi Genel Müdürlüğü (2019), Geçici Koruma. 15 Aralık 2019 tarihinde https://www.goc.gov.tr/gecici-koruma5638 adresinden edinilmiştir. Erişim tarihi 12.09.2019.

Gökçe, B. (1977), Gecekondu Gençliği, Hacettepe Üniversitesi. Yayınları, Ankara.

Gökulu G. (2010), Kent Güvenliği Kentleşme ve Suç İlişkisi, Atatürk Üniversitesi İktisadi ve Idari Bilimler Dergisi, Cilt: 24, Say1: 1.

İktisadi Kalkınma Vakfı (2016), Mülteci Krizi Ekseninde Türkiye-AB İşbirliği, İktisadi Kalkınma Vakf Yayınları, Yayın No: 289.

Karaca, S., Doğan, U. (2014), Suriyeli Göçmenlerin Sorunları Çalıştayı Sonuç Raporu, Mersin Üniversitesi Yayını.

Karadağ, A. (2014), Suriyeli Yeni Komşularımız, Geri Dönmeyi Düşünmüyorlar. 10 Ekim 2019 tarihinde http://www.yurtsuz.net/News.aspx?newsid=1902\#U96VxPl_tu4 adresinden edinilmiştir. 
Karasu M. A. (2016), Şanlıurfa'da Yaşayan Suriyeli Sı̆̆ınmacıların Kentle Uyum Sorunu, Süleyman Demirel Üniversitesi İktisadi ve İdari Bilimler Fakültesi Dergisi, Cilt 21, Sayı 3, s. 997-1016.

Karasu M. A. (2018), Türkiye'deki Suriyeli Sığınmacıların Kentlerde Neden Oldukları Güvenlik Riskleri, Hacettepe Üniversitesi İktisadi ve İdari Bilimler Fakültesi Dergisi, Cilt 36, Say1 2, s. 51-73.

Kaya A. (2016), Türkiye'deki Entegrasyon Retoriğinin Kökleri, Mülteci Krizi Ekseninde Türkiye-AB İşbirliği, İktisadi Kalkınma Vakfı Yayınları, Yayın No: 289.

Kaya, F. (2018) Türkiye'nin AB üyeliği Açısından Kıbrıs Sorunu, Akademik Bakış Dergisi, Say1 66, ss.184-195.

Kaypak Ş. ve Bimay M. (2016), Suriye Savaşı Nedeniyle Yaşanan Göçün Ekonomik ve Sosyokültürel Etkileri: Batman Örneği, Batman Üniversitesi Yaşam Bilimleri Dergisi; Cilt 6 Sayı 1.

Kearney, R. (2018), Yabancılar, Tanrılar ve Canavarlar Ötekiliği Yorumlamak, İstanbul, Metis Yayinlar1.

Kirişçi K. (2014), Misafirliğin Ötesine Geçerken: Türkiye’nin Suriyeli Mülteciler Sinavı, İngilizceden Çev. Sema Karaca, Brookıngs Enstitüsü ve Uluslararası Stratejik Araştırmalar Kurumu (USAK).

Kuş, O. (2016), Dijital Nefret Söylemini Anlamak: Suriyeli Mülteci Krizi Örnek Olayı Bağlamında BBC WORLD SERVİCE Web sayfasına Gelen Yorumların Metin Madenciliği Tekniği İle Analizi, Istanbul Üniversitesi İletişim Fakültesi Dergisi, s.97-121.

Küçükdoğru S. (2011), Polislik Mesleğinin ve Polis Meslek Yüksekokullarında Verilen İnsan Hakları Ĕgitiminin Irdelenmesi, Maltepe Üniversitesi Sosyal Bilimler Enstitüsü İnsan Hakları Anabilim Dalı, Yüksek Lisans Tezi.

Küçükdoğru S. (2019), Avrupa Birliği’nin Adalet ve Iç̧işleri Politikası İle Türkiye'nin Uyum Süreci: Bir Araştırma, İstanbul Üniversitesi Sosyal Bilimler Enstitüsü Avrupa Birliği Anabilim Dalı, Doktora Tezi.

Leones, S. V. C. (2006), The Current Situation of Crime Associated with Urbanization: Problems Experienced and Countermeasures Initiated in the Philippines, United Nations Asia and Far East Instutue for the Prevention of Crime and the Treatment of Offenders(UNAFEI) ,Research Material Series; vol. 68, Tokyo Japan p 133-150.

Memiş, H. (2015), İç Savaş Nedeniyle Kilis'te Yaşayan Suriyelilerin Oluşturduğu Sosyoekonomik Algılar Üzerine Bir Araştırma, E-SOSDER, 14(52), s.100-114.

Milliyet Gazetesi (2018), Suriyelilerin karıştığı olaylar. 15 Aralık 2019 tarihinde https://www.milliyet.com.tr/icisleri-bakani-soylu-muhtarlar-siyaset-2763351/, adresinden edinilmiştir.

Mutlu P., Mısırlı K., Kahveci M., Akyol E., Erol E., Gümüşcan İ., Pınar E., Salman C. (2018), Suriyeli Göçmen İşçilerin İstanbul Ölçeğinde Tekstil Sektörü Emek Piyasasına Eklemlenmeleri ve Etkileri, Çalışma ve Toplum: Ekonomi ve Hukuk Dergisi, Sayı 56, s. 69-92.

SABR-MDD (2015), Suriyeli-Türk Uyumu Gaziantep'teki Suriyelileri ve Türklerin Uyumu Araştırması, SABR Araştırma Merkezi. 


Sahil Güvenlik Komutanlı̆̆ $\quad$ (2017), $\quad$ (Çevrimiçi)
http://www.sahilguvenlik.gov.tr/baskanliklar/harekat/faaliyet_istatistikleri/faaliyet_istatistikle ri.asp, Mart 2017. Erişim: 12.09.2019

Sencer, Y. (1979), Türkiye'de Kentleşme: Bir Toplumsal ve Kültürel Değişme Süreci, Kültür Bakanlığı, Ankara.

Taşkın D. (2016), Mültecilerin İşgücü Piyasasına Erişim Anahtarı: Çalışma İzni Yönetmeliği, Mülteci Krizi Ekseninde Türkiye-AB İşbirliği, İktisadi Kalkınma Vakfı Yayınları, Yayın No: 289.

TBMM İnsan Hakları İnceleme Komisyonu (2012), Ülkemize sığınan Suriye vatandaşlarının barındıkları çadır kentler hakkında inceleme raporu, 24. Dönem 1. ve 2. Yasama Yılları Faaliyet Raporu, Ankara.

Uluslararası Af Örgütü (2017), Dünyada İnsan Haklarının Durumu. 02 Kasım 2019 tarihinde https://www.amnesty.org/download/Documents/POL1048002017TURKISH.PDF adresinden edinilmiştir.

UNCHR (2015), http://www.unhcr.org.tr/ Erişim tarihi: 18 Kasım 2019.

United Nations. (2017). International Migration Report 2017. New York: United Nations. 20 Kasım 2019 tarihinde https://www.un.org/development/desa/publications/internationalmigration-report-2017.html adresinden edinilmiştir.

Urfa Haber (2016), Urfa'da hastalık oranı arttı 15 Kasım 2019 tarihinde http://www.urfahaber.com/urfa-haberleri/urfada-hastalik-orani-arti adresinden edinilmiştir.

Ünal S. (2014), Türkiye’nin Beklenmedik Konukları: “Öteki” Bağlamında Yabancı Göçmen ve Mülteci Deneyimi, Zeitschrift Für Die Welt Der Türken / Journal Of World Of Turks, Vol 6, No 3.

Vural B. M. (2017), Suriyeli Sığınmacıların Türkiye Ekonomisine Etkileri, Türkiye-AB Iliş̧kilerinde Yeni Bir Konu: Mülteci Sorunu ve Türkiye-AB İşbirliği, Editörler: Yaprak Gülcan, Sedef Akgüngör, Yeşim Kuştepeli, İktisadi Kalkınma Vakfi Yayınları, Yayın No: 293.

Yıldırım, K., Aykaç, N. ve Okçu, S. T. (2019), Yaratıcı Drama ve Resimli Çocuk Kitapları, Kültürlerarası Duyarlılı̆̆1 Geliştirmek İçin Örnek Bir Uygulama, Yaratıcı Drama Dergisi, 14 (1), 55-72.

İçişleri Bakanlığı (2017), (Çevrimiçi) https://www.icisleri.gov.tr/basin-aciklamasi, Temmuz 2017. Erişim: 15 Eylül 2019.

$\begin{array}{llll}\text { Türkiye } & \text { İstatistik } & \text { Kurumu } & \text { (2019). }\end{array}$ http://www.tuik.gov.tr/PreTablo.do?alt_id=1007, erişim tarihi: 25 Kasım 2019.

Türkiye İstatistik Kurumu (2019). (Çevrimiçi) http://www.tuik.gov.tr/UstMenu.do?metod=temelist, erişim tarihi: 30 Kasım 2019. 